\title{
T lymphocytes facilitate brain metastasis of breast cancer by inducing Guanylate-Binding Protein 1 expression
}

\author{
Dana A. M. Mustafa ${ }^{1,2} \cdot$ Rute M. S. M. Pedrosa $^{1} \cdot$ Marcel Smid $^{3} \cdot$ Marcel van der Weiden $^{1} \cdot$ Vanja de Weerd $^{3}$. \\ Alex L. Nigg ${ }^{1,4} \cdot$ Cor Berrevoets $^{5} \cdot$ Lona Zeneyedpour $^{6} \cdot$ Neibla Priego $^{7} \cdot$ Manuel Valiente $^{7} \cdot$ Theo M. Luider $^{6}$. \\ Reno Debets ${ }^{5} \cdot$ John W. M. Martens ${ }^{3} \cdot$ John A. Foekens ${ }^{3} \cdot$ Anieta M. Sieuwerts $^{3} \cdot$ Johan M. Kros ${ }^{1,2}$
}

Received: 10 October 2017 / Revised: 9 January 2018 / Accepted: 9 January 2018 / Published online: 19 January 2018

(c) The Author(s) 2018. This article is an open access publication

\begin{abstract}
The discovery of genes and molecular pathways involved in the formation of brain metastasis would direct the development of therapeutic strategies to prevent this deadly complication of cancer. By comparing gene expression profiles of Estrogen Receptor negative (ER-) primary breast tumors between patients who developed metastasis to brain and to organs other than brain, we found that $\mathrm{T}$ lymphocytes promote the formation of brain metastases. To functionally test the ability of $\mathrm{T}$ cells to promote brain metastasis, we used an in vitro blood-brain barrier (BBB) model. By co-culturing T lymphocytes with breast cancer cells, we confirmed that $\mathrm{T}$ cells increase the ability of breast cancer cells to cross the BBB. Proteomics analysis of the tumor cells revealed Guanylate-Binding Protein 1 (GBP1) as a key T lymphocyte-induced protein that enables breast cancer cells to cross the BBB. The GBP1 gene appeared to be up-regulated in breast cancer of patients who developed brain metastasis. Silencing of GBP1 reduced the ability of breast cancer cells to cross the in vitro BBB model. In addition, the findings were confirmed in vivo in an immunocompetent syngeneic mouse model. Co-culturing of ErbB2 tumor cells with activated T cells induced a significant increase in Gbpl expression by the cancer cells. Intracardial inoculation of the co-cultured tumor cells resulted in preferential seeding to brain. Moreover, intracerebral outgrowth of the tumor cells was demonstrated. The findings point to a role of $\mathrm{T}$ cells in the formation of brain metastases in ER- breast cancers, and provide potential targets for intervention to prevent the development of cerebral metastases.
\end{abstract}

Keywords Brain metastasis $\cdot$ Blood-brain barrier $\cdot \mathrm{T}$ cell response $\cdot G B P 1$

Electronic supplementary material The online version of this article (https://doi.org/10.1007/s00401-018-1806-2) contains supplementary material, which is available to authorized users.

Johan M. Kros

j.m.kros@erasmusmc.nl

1 Department of Pathology, Erasmus Medical Center, Wytemaweg 80, 3000 DR Rotterdam, The Netherlands

2 Brain Tumor Center, Erasmus Medical Center, Rotterdam, The Netherlands

3 Department of Medical Oncology, Erasmus MC Cancer Institute, Rotterdam, The Netherlands

4 Department of Pathology, Optical Image Center, Erasmus Medical Center, Rotterdam, The Netherlands

\section{Introduction}

Breast cancer is among the tumors that most frequently metastasize to brain [30, 37, 38, 40, 43, 49, 57]. The appearance of metastases in brain invariably defines the terminal stage of disease for women suffering from disseminated breast cancer and the prevention of cerebral spread would

5 Department of Medical Oncology, Laboratory of Tumor Immunology, Erasmus Medical Center, Rotterdam, The Netherlands

6 Department of Neurology, Laboratory for Neuro-Oncology, Erasmus Medical Center, Rotterdam, The Netherlands

7 Brain Metastasis Group, Spanish National Cancer Research Center (CNIO), 28029 Madrid, Spain 
significantly improve their survival [44]. The formation of cerebral metastases depends on the capability of circulating tumor cells to successfully penetrate the blood-brain barrier (BBB). Various genes and pathways have been associated with seeding of breast cancer cells to various organs and the rise of brain metastases in particular [6, 32, 47, 52, 54]. Several associations between innate features of the primary tumors and their propensity to intracerebral seeding have been reported. HER2-enriched (HER2 +) and triple-negative (TNBC) primary tumors are at higher risk for developing brain metastases relative to the hormone receptor-positive tumors [17, 18, 29, 53, 59]. So far, ST6GALNAC5 is the only specific gene that was found to mediate the formation of brain metastases of a human breast cancer-derived cell line when injected in mice. Moreover, its expression in human breast cancer samples appeared to be associated with the occurrence of cerebral metastases [3]. However, the identification of pathways associated with brain metastasis is necessary to elucidate the mechanisms of crossing the BBB and developing strategies to prevent the formation of brain metastasis.

Here, we sought pathways specifically involved in the formation of cerebral metastases of breast cancer by comparing RNA expression profiles of primary ER- breast cancer samples of patients who developed cerebral metastases, with those who developed metastasis to other organs but not to brain. We discovered that the $\mathrm{T}$ cell response is crucial for the development of brain metastases. In both in vitro studies using a BBB model and in vivo studies using a mouse model, $T$ cells appear to change the expressional profiles of the breast cancer cells and facilitate their passage through the BBB. Guanylate-binding protein 1 (GBP1) is prominent among the involved proteins and its expression appears to be upregulated in the primary tumor specimens. Silencing of $G B P 1$ significantly decreased the ability of breast cancer cells to cross the BBB. The involvement and specific action of $\mathrm{T}$ lymphocytes in the process of cerebral metastasis is novel, and opens new therapeutic opportunities for preventing tumor cells to enter the brain.

\section{Methods}

\section{Tissue sample selection}

To identify genes and pathways involved in the formation of brain metastasis, we exclusively used specimens of primary tumors, and did not use specimens of metastatic sites. Fresh frozen (FF) tissue specimens of 22 primary breast cancer patients who developed metastasis to brain and/or to other organs were selected. Two groups of samples were compared; those from patients who had developed brain metastasis (exclusively or in addition to a maximum of 2 organs; $n=13)$ and those from women who developed metastases to a maximum of three organs $(n=9)$. None of the 22 patients had received adjuvant therapy (chemo- or hormonal therapy) prior to developing metastases, all samples were ER- and none of the patients had more than three metastatic sites. The relevant clinical data are provided in Table 1 . In addition, we used 20 primary breast cancer samples for independent validations from patients of whom 13 developed brain metastasis. This study was approved by the Medical Ethics Committee of the Erasmus Medical Center, Rotterdam, The Netherlands (MEC 02.953) and performed in adherence to the Code of Conduct of the Federation of Medical Scientific Societies in The Netherlands (http://www.fmwv.nl/).

\section{Morphological assessment}

$5 \mu \mathrm{m}$ H\&E sections from each sample were prepared before and after sectioning for RNA isolation. To ascertain the origin of the tumor, the percentages of the invasive tumor cells, inflammatory infiltrates and the presence of necrosis were taken into consideration (JMK).

\section{RNA extraction and purification and quality control}

Total RNA from FF tissue samples was extracted from 20 to 30 sections of $30 \mu \mathrm{m}$ (depending on the size of the sample) using RNABee reagent according the supplier's instructions (Campro Scientific, Veenendaal, The Netherlands) [50]. Following isolation, RNA was stored in RNase/DNase-free water at $-80^{\circ} \mathrm{C}$. The quantity and quality of the isolated RNA was assessed by nanodrop. Samples were excluded if the yield did not reach the minimum requirement of $1000 \mathrm{ng}$.

\section{Gene expression profiling}

Illumina Whole-Genome cDNA-mediated Annealing, Selection, extension and Ligation (WG-DASL) assay was used to profile the samples. In the assay, 24,526 annotated transcripts corresponding to 18,391 unique genes are measured. The WG-DASL assay was performed according to the manufacturer's instructions with an input of $500 \mathrm{ng}$ total RNA. To monitor the assay performance and to evaluate the interassay BeadChip variability between the experiments, an inner-assay control consisting of $500 \mathrm{ng}$ total RNA pooled from RNA isolated from several cultured breast cancer cell lines was used in each experiment [36].

\section{Data analysis}

Scanned data were uploaded into GenomeStudio software version 2011.1 via the WG-DASL gene expression module for further analysis. The average signal, detection $P$ value, bead standard error and average beads were used to quantile 
Table 1 Clinical information

\begin{tabular}{|c|c|c|c|c|c|c|c|c|}
\hline Samples & $\begin{array}{l}\text { Age at } \\
\text { diagnosis } \\
\text { (years) }\end{array}$ & ER & PR & HER2/neu & $\begin{array}{l}\text { Metastasis- } \\
\text { free period } \\
\text { (months) }\end{array}$ & $\begin{array}{l}\text { First metastasis } \\
\text { site/s }\end{array}$ & $\begin{array}{l}\text { Subsequent } \\
\text { metastasis site/s }\end{array}$ & follow-up (months) \\
\hline \multicolumn{9}{|l|}{ Discovery } \\
\hline 1 & 41 & 0 & 0 & 0 & 9 & brain & & 14 \\
\hline 2 & 48 & 0 & 0 & 0 & 51 & brain & & 55 \\
\hline 3 & 62 & 0 & 0 & 0 & 7 & brain & & 8 \\
\hline 4 & 51 & 0 & 0 & 0 & 16 & $\begin{array}{l}\text { brain }+ \text { lung }+ \\
\text { pleura }\end{array}$ & & 23 \\
\hline 5 & 51 & 0 & 0 & 1 & 12 & brain & & 18 \\
\hline 6 & 53 & 0 & 0 & 0 & 16 & brain + liver & & 18 \\
\hline 7 & 41 & 0 & 0 & 0 & 25 & brain + lung & liver & 54 \\
\hline 8 & 49 & 0 & 0 & 0 & 37 & brain + lung & skin & 39 \\
\hline 13 & 52 & 0 & 0 & 1 & 12 & bone + brain & & 13 \\
\hline 9 & 38 & 0 & 0 & 0 & 23 & skin + lung & brain + bone & 41 \\
\hline 10 & 58 & 0 & 0 & 0 & 8 & lung & brain & 20 \\
\hline 11 & 58 & 0 & 0 & 0 & 30 & liver & brain & 45 \\
\hline 12 & 35 & 0 & 0 & 0 & 29 & bone & brain & 63 \\
\hline 14 & 45 & 0 & 0 & 0 & 4 & skin & & 9 \\
\hline 15 & 44 & 0 & 0 & 0 & 22 & bone & & 35 \\
\hline 16 & 35 & 0 & 0 & 0 & 7 & liver + lung & & 18 \\
\hline 17 & 40 & 0 & 0 & 0 & 33 & bone + lung & & 65 \\
\hline 18 & 66 & 0 & 0 & 0 & 5 & pleura & & 12 \\
\hline 19 & 57 & 0 & 0 & 0 & 14 & bone + lung + pleura & & 22 \\
\hline 20 & 45 & 0 & 0 & 1 & 17 & liver + bone & & 29 \\
\hline 21 & 70 & 0 & 0 & 0 & 17 & liver + bone + lung & & 20 \\
\hline 22 & 44 & 0 & 0 & 0 & 9 & bone + lung & & 22 \\
\hline
\end{tabular}

\begin{tabular}{|c|c|c|c|c|c|c|c|c|}
\hline \multicolumn{9}{|l|}{ Validation } \\
\hline 1 & 49 & 0 & 0 & 1 & 19 & brain & & 19 \\
\hline 2 & 39 & 0 & 0 & 0 & 51 & brain & & 60 \\
\hline 3 & 53 & 0 & 0 & 1 & 63 & brain & & 69 \\
\hline 4 & 56 & 0 & 0 & 0 & 6 & brain & & 7 \\
\hline 5 & 35 & 0 & 0 & 0 & 23 & brain & & 118 \\
\hline 6 & 39 & 0 & 0 & 0 & 59 & brain & & 88 \\
\hline 7 & 74 & 0 & 0 & 0 & 8 & brain & & 14 \\
\hline 8 & 29 & 0 & 0 & 0 & 116 & brain & & 154 \\
\hline 9 & 49 & 0 & 0 & 1 & 13 & brain & bone & 50 \\
\hline 10 & 38 & 0 & 0 & 0 & 12 & brain & lung + skin & 16 \\
\hline 11 & 53 & 0 & 0 & 1 & 35 & brain & other breast & 169 \\
\hline 12 & 59 & 0 & 0 & 1 & 19 & brain & lung + liver & 52 \\
\hline 13 & 47 & 0 & 0 & 1 & 16 & brain + lung & & 18 \\
\hline 14 & 69 & 0 & 0 & 1 & 14 & skin & & 39 \\
\hline 15 & 56 & 0 & 0 & 0 & 13 & bone & & 28 \\
\hline 16 & 57 & 0 & 0 & 0 & 61 & bone + lung & & 61 \\
\hline 17 & 69 & 0 & 0 & 1 & 7 & liver & & 7 \\
\hline 18 & 58 & 0 & 0 & 0 & 9 & pleura & & 12 \\
\hline 19 & 31 & 0 & 0 & 0 & 12 & pleura & liver + bone & 12 \\
\hline 20 & 36 & 0 & 0 & 0 & 159 & lung & kidney & 241 \\
\hline
\end{tabular}

Age at diagnosis in years; metastasis-free periods and follow-up in months. For ER, PR, HER2/neu status: $0=$ negative, $1=$ positive

normalize the data in the statistical language R (www.r-proj ect.org) using the "Lumi" package [11].
To identify significantly differentially expressed genes, three steps were followed: sample exclusion criterion, 
reliable probe selection and gene expression comparisons. Sample exclusion criterion and probe selection method were described previously [36]. For the gene expression comparison, Biometric Research Branch ArrayTools (BRB-array tool (V4.3.1)) was used [51]. Within BRB, the 4150 most reliable probes for FF samples were exposed to the class comparison algorithm to identify differentially expressed genes with a maximum $P$ value of 0.05 after 10,000 permutations multiple correction to determine significance.

\section{Pathway analysis}

Pathway analysis was done by two different methods. Firstly, the differentially expressed genes (resulted from the gene expression comparisons of samples with brain metastasis compared to samples with metastasis to other organs) was submitted to Ingenuity Pathway Analysis (Ingenuity, Mountain View, CA). Secondly, all reliably profiled genes were submitted to the Global Test [16] (version 4.4.0) to associate Biocarta pathways (www.biocarta.com) to the groups of samples metastasizing to brain or to other organs. The $\mathrm{R}$ version 2.4.1 (www.r-project.org) was used to run the Global Test package. A $P$ value for a pathway was considered significant when the univariate $P$ value of the test as well as the $P$ value calculated by 1000 re-samplings were both $<0.05$. In addition, The lists of differentially expressed probes were uploaded into the function annotation tool DAVID version 6.7 [9] to functionally annotate the differentially expressed genes. DAVID was used with the data basses and settings that are preselected by default. Statistical analyses and multiple testing correction procedures are those included in the DAVID analyses [21].

\section{In vitro BBB model}

\section{Tissue culture procedures}

Human umbilical vein endothelial cells (HUVECs, ScienCell) were cultured in endothelial cell medium (ECM, ScienCell) supplemented with endothelial cells growth factors, 5\% fetal bovine serum and Penicillin/Streptomycin. HUVECs were used between passage 2 and 5. Human astrocytes (ScienCell) were cultured in astrocytes medium (AM, ScienCell) supplemented with astrocyte growth factors, $2 \%$ fetal bovine serum and Penicillin/Streptomycin. Human astrocytes were used between passage 2 and 5 . No further authentication was performed for this study for HUVECs and human astrocytes. Three breast cancer cell lines which had proven to be able to cross the BBB were used: MDAMB-231, MDA-MB-231-BM (a breast cancer cell line that metastasize specifically to brain) [3] and SUM159PT [45]. The characterization of the breast cancer cell lines are summarized (Supplementary Table 1). The tumor cell lines and normal fibroblasts (isolated from non-cancerous tissue) were previously characterized $[19,46]$, and were cultured in RPMI medium supplemented with L-glutamine, $10 \%$ fetal bovine serum and Penicillin/Streptomycin. T cells were isolated, activated and transduced as described previously $[24,55]$. Two types of $T$ cells were used: $T$ cells that were transduced with an empty vector, referred to as "T cells", and $\mathrm{T}$ cells that were transduced with a $\mathrm{T}$ cell receptor specific for MAGE-C2/HLA-A2 vector, referred to as "antigenspecific T cells". The later T cells allowed studies into the role of antigen-specific activation of $\mathrm{T}$ cells, to which end SUM159PT cells were used as these cells express the cognate antigen (MAGE-C2/HLA-A2). Both types of T cells were cultured in RPMI media, supplemented with $10 \%$ fetal bovine serum and IL-2 (360 IU/mL, Chiron, Amsterdam, The Netherlands), and Penicillin/Streptomycin. The T cell transduction process, validation of TCR expression by flow cytometry and particular culture conditions by allogeneic feeder cells are described in $[24,55]$.

\section{Construction of the in vitro BBB assays}

To develop a BBB model, HUVECs were co-cultured with human astrocytes on opposite sides of a transwell insert [13]. Twenty-four-wells transwell polycarbonate inserts (surface area $0.33 \mathrm{~cm}^{2}$, pore size $3 \mu \mathrm{m}$, Becton Drive, Franklin Lakes, NJ, USA) were coated with $2 \%$ gelatin (Sigma) for $45 \mathrm{~min}$. The transwell inserts were placed upside-down and $\sim 100,000$ human astrocytes/inserts were seeded at the bottom side of the inserts. The cells were allowed to adhere for $3 \mathrm{~h}$ at $37{ }^{\circ} \mathrm{C}$ in a $5 \% \mathrm{CO}_{2}$ incubator and were fed every 15-30 min. After $3 \mathrm{~h}$, inserts were flipped and placed in 24-well plates. $1 \mathrm{~mL}$ of astrocyte media was added to the lower chamber and astrocytes were allowed to grow for 1 day. Fifty-thousand endothelial cells were plated on the upper chamber of the inserts and the cultures were placed in the incubator for 3 days. The permeability of the BBB model was verified by adding trypan blue dye to the upper chamber and incubating the model for $30 \mathrm{~min}$ at $37^{\circ} \mathrm{C}$. Medium from the lower chamber was collected and absorbance was measured at $595 \mathrm{~nm}$. The permeability of the BBB model by trypan blue was included in duplicate in each experiment.

\section{In vitro BBB-T cell response functional studies}

To investigate the influence of T lymphocytes on the ability of tumor cells to cross the BBB, MDA-MB-231, MDAMB-231-BM and SUM159PT breast cancer cells were co-cultured with $\mathrm{T}$ cells (no specific binding occurred between $\mathrm{T}$ cells and breast cancer cells). In addition, SUM159PT breast cancer cells were co-cultured with antigen-specific T cells (specific binding occurred between $\mathrm{T}$ cells and breast cancer cells). The optimal ratio of tumor 
cells and $\mathrm{T}$ cells was achieved following a titration to reach the best balance between cell killing and migration. The co-culture ratio of breast cancer cells over $\mathrm{T}$ cells was $3: 1$. After co-culturing for 3 days, $T$ cells were removed by three washes using PBS. The breast cancer cells were harvested and labelled with $5 \mu \mathrm{M}$ CFMDA cell tracker green (Invitrogen) for $45 \mathrm{~min}$ in serum-free medium. The breast cancer cells were collected and re-suspended in RPMI medium supplemented with L-glutamine, $10 \%$ fetal bovine serum and Penicillin/Streptomycin. Ten thousand cells were seeded in the upper chamber of the BBB model and incubated overnight at $37{ }^{\circ} \mathrm{C}$. The cells which had passed through were recorded by confocal microscopy of the lower chamber after removing the transwell inserts.

To investigate whether the cytokines secreted by $\mathrm{T}$ cells are responsible for the changes of breast cancer cells, cells of the three breast cancer cell lines were incubated with $5 \mathrm{ml}$ conditioned media collected from $\mathrm{T}$ cells for 3 days. Then breast cancer cells were washed, harvested and labelled using the same method as described above. Ten-thousand cells were seeded on the upper chamber of the insert and incubated overnight at $37^{\circ} \mathrm{C}$. As a control, ten-thousand breast cancer cells of the three breast cancer cell lines, without exposure to either T cells or to conditioned media from $\mathrm{T}$ cells, were used. These experiments were repeated 10 times. As a negative control, fibroblasts isolated from non-cancerous tissue were used.

To study the effect of IL-2 (which is essential in culturing T cells) and IFN- $\gamma$ (a cytokine produced by $\mathrm{T}$ cells) the three types of breast cancer cell lines were incubated with IL-2 (360 IU/ml) and with IFN- $\gamma(10$ and $20 \mu \mathrm{g}$, Bio-Connect, Huissen, The Netherlands) separately for 3 days. Subsequently, breast cancer cells were washed, labelled with cell tracker green and seeded in the upper chamber of the BBB model. These experiments were repeated three times. Moreover, to study the effects of $\mathrm{T}$ cells, conditioned media of T cells, IL-2 and IFN- $\gamma$, on the permeability of the BBB model, they were added to the upper chamber of the BBB model and incubated overnight. Subsequently, the permeability of the BBB model was investigated by adding trypan-blue dye (20\% in RPMI media) to the upper chamber and incubated for $30 \mathrm{~min}$ at $37{ }^{\circ} \mathrm{C}$. Medium from the lower chamber was collected and absorbance was measured at $595 \mathrm{~nm}$. In addition, the effect of the mentioned factors on the permeability of the BBB model was checked by seeding breast cancer cells in the upper chamber of the BBB model overnight. These experiments were repeated three times.
Confocal laser-scanning microscopy and Quantification of the migrated cells

Confocal images were obtained using a Zeiss LSM510 confocal laser-scanning microscope equipped with a $488 \mathrm{~nm}$ Argon-laser and a Plan-Neofluar $20 \times$ objective with NA 0.5 (Zeiss, Oberkochen, Germany). Images were made with a pixelsize of $0.9 \mu \mathrm{m}$. Pictures were submitted to ImageJ software version $1.49 \mathrm{~S}$ (http://www.fiji.sc) and used to calculate the number of cells per $\mathrm{mm}^{2}$.

\section{Proteomics measurements}

MDA-MB-231 and MDA-MB-231-BM breast cancer cells were co-cultured with T cells in 3: 1 ratio, and SUM159PT was co-cultured with antigen-specific T cells for 3 days (following the same method described earlier). As controls, MDA-MB-231, MDA-MB-231-BM and SUM159PT cells were cultured without $T$ cells for 3 days. All cell cultures were washed three times with PBS to remove $T$ cells before they were scraped and collected in $1.5 \mathrm{~mL}$ Eppendorf tubes. Three additional washing steps with PBS were applied. After removing the supernatant, the cell pellets were immediately snap-frozen on dry-ice and stored in $-80{ }^{\circ} \mathrm{C}$ until the time of preparation. After thawing the samples, they were prepared and measured on nano LC as described previously [35].

\section{Proteomics data analysis}

From the raw data files of the Orbitrap Fusion mass spectrometer, MS/MS spectra were extracted and converted into mgf files using MSConvert of ProteoWizard1 (version 3.0.06245). All mgf files were analyzed using Mascot (version 2.3.02; the Matrix Science, London, UK), which was used to perform searches against the Uniprot_sprot_2014_09 database; Homo sapiens species restriction; 66,244 sequences. For the database search the following settings were used: a maximum of two miss cleavages, oxidation as a variable modification of methionine, carbamidomethylation as a fixed modification of cysteine and trypsin was set as enzyme. A peptide mass tolerance of $10 \mathrm{ppm}$ and a fragment mass tolerance of $0.5 \mathrm{Da}$ were allowed. An ion score of 40 was used as cut-off value.

Scaffold software (version 4.4.3, Portland, OR) was used to summarize and filter MS/MS based peptides and protein identifications. Protein identifications were accepted if they could be established at greater than $99.0 \%$ probability and contained at least two identified peptides. Proteins that contained similar peptides and could not be differentiated based on MS/MS analysis alone were grouped. Using these criteria, Scaffold generated a list of identified proteins (Minimum: $6 \%$ coverage and 2 peptides), including the number of 
sequenced peptides that corresponded to these proteins. The identified proteins of breast cancer cells (of the three cell lines) that were co-cultured with $\mathrm{T}$ cells were compared to those of the breast cancer cells cultured without the T cells. The comparison was done based on 2 sample $t$ test, and the $P$ values of all proteins were calculated and corrected for multiple variants using Benjamini-Hochberg. A protein was considered as a differentially expressed protein if $P<0.05$, and all three breast cancer cell lines in one group showed the same direction of expression.

The mass spectrometry proteomics data have been deposited to the ProteomeXchange Consortium via the PRIDE [60] partner repository with the dataset identifier PXD006750.

\section{GBP1 silencing}

To study the role of GBPl in crossing the BBB by the tumor cells, silencing transfection experiments were performed. A mix of four siRNA sequences that target GBP1 mRNA and another mix of non-targeting siRNA (referred to as siSham) were obtained from Dharmacon (GE health care, The Netherlands). Silencing experiments were performed using transfection buffer 1, following the manufacturer's instructions (Dharmacon, GE health care, The Netherlands). MDAMB-231 and MDA-MB-231-BM breast cancer cell lines were transfected for $24 \mathrm{~h}$. RNA was isolated using RNeasy Micro Kit (Qiagen), and the silencing efficiency was evaluated by reverse transcriptase quantitative PCR (RT-qPCR) using TaqMan gene expression assay (Applied Biosystems).

When siGBP1 proved to be efficient, the transfection experiments were performed for $24 \mathrm{~h}$, then breast cancer cells were co-cultured with $\mathrm{T}$ cells ( $3: 1$ ratio) for an additional $24 \mathrm{~h}$. The co-culturing time was reduced to $24 \mathrm{~h}$, well within the effective period of siGBP1. Afterward, T cells were washed away with PBS, and breast cancer cells were harvested and labelled with green tracker as described above. Ten-thousand cells were seeded on the upper chamber of the BBB model as described above.

Immunohistochemistry Formalin fixed, paraffin embedded (FFPE) tissue samples that morphologically matched the primary FF tissues were used to perform immunohistochemistry. We retrieved 11 FFPE samples of the $22 \mathrm{FF}$ samples that were used for discovery. The $\mathrm{T}$ cell markers were stained with an automated IHC staining system (Ventana BenchMark ULTRA; Ventana Medical System Inc. Tucson, AZ). CD3 $(0.4 \mu \mathrm{g} / \mathrm{mL}$, clone 2GV6, Ventana, Tuscan, AZ) antibody was used as general marker for T cells; CD4 $(2.5 \mu \mathrm{g} / \mathrm{mL}$, clone PS35, Ventana, Tuscan, AZ) and CD8 (1:100 dilution, clone C8/144B, Dako, Heverlee, Belgium) were used as markers for $\mathrm{T}$ helpers and $\mathrm{T}$ cytotoxic subsets, respectively. The staining was performed according to the manufacture instructions. In addition, GBP1 (1:250 dilution, Santa Cruz Biotechnology, Heidelberg Germany) was used according to the manufacture instructions. In addition to the 11 FFPE samples of the discovery set, we used 20 independent samples for extra validation. The clinical information of the samples is summarized in Table 1.

\section{In vivo mouse model}

\section{T cell isolation and tissue culture}

T cells were obtained from the spleen of 4-6-week-old FVB mice weeks. Splenocytes were sorted using anti-mouse CD4-Pe (BD Pharmigen catalog. 553048) and activated with anti-mouse CD3e clone 145-2C11 (BD Pharmigen catalog. 553066) coated plates, soluble anti-mouse CD28 (37.51) (Tonbo Biosciences catalog. 70-0281-U500), and mouse IL-2 (Miltenyi Biotec catalog. 130-094-054). The ErbB2$\mathrm{P}$ cell line was established from MMTV driven-NeuNT transgenic mammary tumors in mice [34]. They express Luciferase and gfp. ErbB2-P are cultured in vitro in DME media supplemented with $10 \%$ fetal bovine serum (FBS), $2 \mathrm{mM}$ L-Glutamine, $100 \mathrm{IU} / \mathrm{ml}$ penicillin/streptomycin, and $1 \mathrm{mg} / \mathrm{ml}$ amphotericin B. The ErbB2-P was co-cultured with $\mathrm{T}$ cells in RPMI medium supplemented with $10 \%$ FBS and Penicillin-Streptomycin for 3 days and then sorted out and injected in syngeneic animals into the heart. 3 weeks later, metastasis burden was analyzed by bioluminescence imaging (BLI).

\section{qRT-PCR}

RNA (QIAGEN) from sorted gfp + ErbB2-P cancer cells was used to generate cDNA (iScript cDNA Synthesis Kit Bio-Rad catalog. 1708890). Gene expression was analyzed using SYBR green gene expression assays $\left(\mathrm{GoTaq}^{\circledR} \mathrm{qPCR}\right.$ Master Mix Promega catalog. A6002). Primers: Gbp1 (Sequence of the primer 5-3): 5'-3'GGGCAGCTGTCT TTGGGTAGAC, 3'-5'AGCATGAGGCCCTAGGAGCTGT. Quantitative PCR reaction was performed on QuantStudio 6 Flex Real-Time PCR System (Applied Biosystems) and analyzed using the software QuantStudio 6 and 7 Flex Software.

\section{Flow cytometry}

ErbB2-P and T cells were isolated from the co-culture based on gfp expression using FACS ARIA Ilu sorter.

\section{Animal experiments}

All animal experiments were done in accordance with a protocol approved by the CNIO, Instituto de Salud Carlos III and Comunidad de Madrid Institutional Animal Care 
and Use Committee. ErbB2-P cells were injected intracardiacally. Briefly, a cell suspension containing $10^{5}$ ErbB2-P cells in a volume of $100 \mu \mathrm{l}$ was injected in the left cardiac ventricle of anesthetized 4-6-week-old FVB mice. Tumor burden was evaluated by bioluminescence imaging using the IVIS-200 imaging system from Xenogen as previously described. Metastases were defined with BLI as those with signal equal or above $2 \times 10^{3}$ photon flux.

\section{Statistics}

$P$ value is calculated using two-tailed $t$ test.

\section{Free-floating immunofluorescence}

Tissue for immunofluorescence was obtained after overnight fixation with PFA $4 \%$ at $4{ }^{\circ} \mathrm{C}$. Slicing of the brain was done using a sliding microtome (Fisher). Brain slices $(80 \mu \mathrm{m})$ were blocked in NGS $10 \%$, BSA $2 \%$, Triton $0.25 \%$ in PBS for $2 \mathrm{~h}$ at room temperature (RT). Primary antibodies were incubated overnight at $4 \mathrm{C}$ in the blocking solution and the following day for $30 \mathrm{~min}$ at RT. After extensive washing in PBS-Triton $0.25 \%$, the secondary antibody was added in the blocking solution and incubated for $2 \mathrm{~h}$. After extensive washing in PBS-Triton $0.25 \%$, nuclei were stained with BisBenzamide for $7 \mathrm{~min}$ at RT. Primary antibody GFP (Aves Labs, ref. GFP-1020, 1:1000). Secondary antibody is AlexaFluor anti-chicken 488 (Invitrogen).

\section{Quantification of brain metastases histology}

80 um sections were obtained from each brain generating 10 series. One series containing 10-12 slices representative of the whole organ was used for immunofluorescence analysis. The staining of gbp1 was performed and positive lesions were quantified under a fluorescence microscope. Total number of metastases per series was obtained and plotted.

\section{Results}

\section{Breast cancers associated with brain metastasis express genes involved in the T lymphocyte response}

Comparing the gene expression profiles of primary breast cancer samples that developed brain metastasis with those that developed metastasis to other organs resulted in 298 differentially regulated genes at $P<0.05$ (Fig. 1a). Among the significant genes, 176 were up-regulated in the group of tumors associated with brain metastasis, while 122 genes were up-regulated in the group associated with metastasis to other organs. To prioritize these genes, we ran functional and pathways analyses. The function annotation tool DAVID revealed that "regulation of T cell activation" was most prominent among the samples associated with brain metastasis $(P$ value $<0.00002$; enrichment score of 6.02$)$. Pathway analysis pointed to a prominent involvement of the " $T$ lymphocyte response" based on both methods (Ingenuity and Global testing) (Tables 2, 3). Moreover, all involved genes in the pathway were up-regulated in the group associated with the brain metastases (Fig. 1b, Table 2).

We screened 11 tumors for the presence of tumor infiltrating lymphocytes (TILs) according to the criteria of the TILs working group 2014 [48], and found that TILs were confined to the stroma surrounding tumor islands in the primary breast cancer samples of patients who had developed metastasis to other organs (Fig. 1c, d). In contrast, TILs had invaded the tumor island in patients who had developed cerebral metastases. This observation suggested that $\mathrm{T}$ cells may play a role in increasing the ability of breast cancer patients to develop brain metastasis.

\section{T lymphocytes increase the ability of breast cancer cells to cross an in vitro BBB model}

To functionally validate the importance of T cells to stimulate brain metastasis, we developed an in vitro BBB model and used three breast cancer cell lines (MDA-MB-231, MDA-MB-231-BM, and SUM159PT). These cell lines are known for their ability to cross the BBB [3, 45], and they all were able to cross the BBB of our in vitro model. However, the number of cells that crossed the artificial BBB overnight was very limited ( $<10$ cells). We co-cultured breast cancer cells with $\mathrm{T}$ cells that were isolated from normal donors for 3 days, removed the $T$ cells and added the breast cancer cells to the BBB model (Fig. 2a). The number of breast cancer cells that crossed the BBB increased significantly (> 300-650 cells) (Fig. 2b, c). To investigate if the interaction between breast cancer cells and $T$ cells was necessary for the dramatic effect that we observed, we run two experiments. First, we incubated breast cancer cells with conditioned media from $\mathrm{T}$ lymphocytes (without including $\mathrm{T}$ cells) and found an increased ability of breast cancer cells to cross the BBB albeit less significantly (> 80-250 cells) (Fig. 2b, c). Second, we co-cultured SUM159PT breast cancer cells (that express the cognate antigen MAGE-C2/HLA-A2) with antigen-specific $\mathrm{T}$ cells $\left(\mathrm{CD}^{+} \mathrm{T}\right.$ lymphocytes transfected with MAGE-C2/HLA-A2 vector). The specific interaction between the breast cancer cells and the T lymphocytes increased the ability of the breast cancer cells to cross the BBB significantly ( $>400$ cells) (Supp. Figure 1). To investigate if $\mathrm{T}$ cells have the same effect on normal cell, we replaced the tumor cells for normal fibroblasts. Co-culturing fibroblasts with $\mathrm{T}$ lymphocytes, or with conditioned 

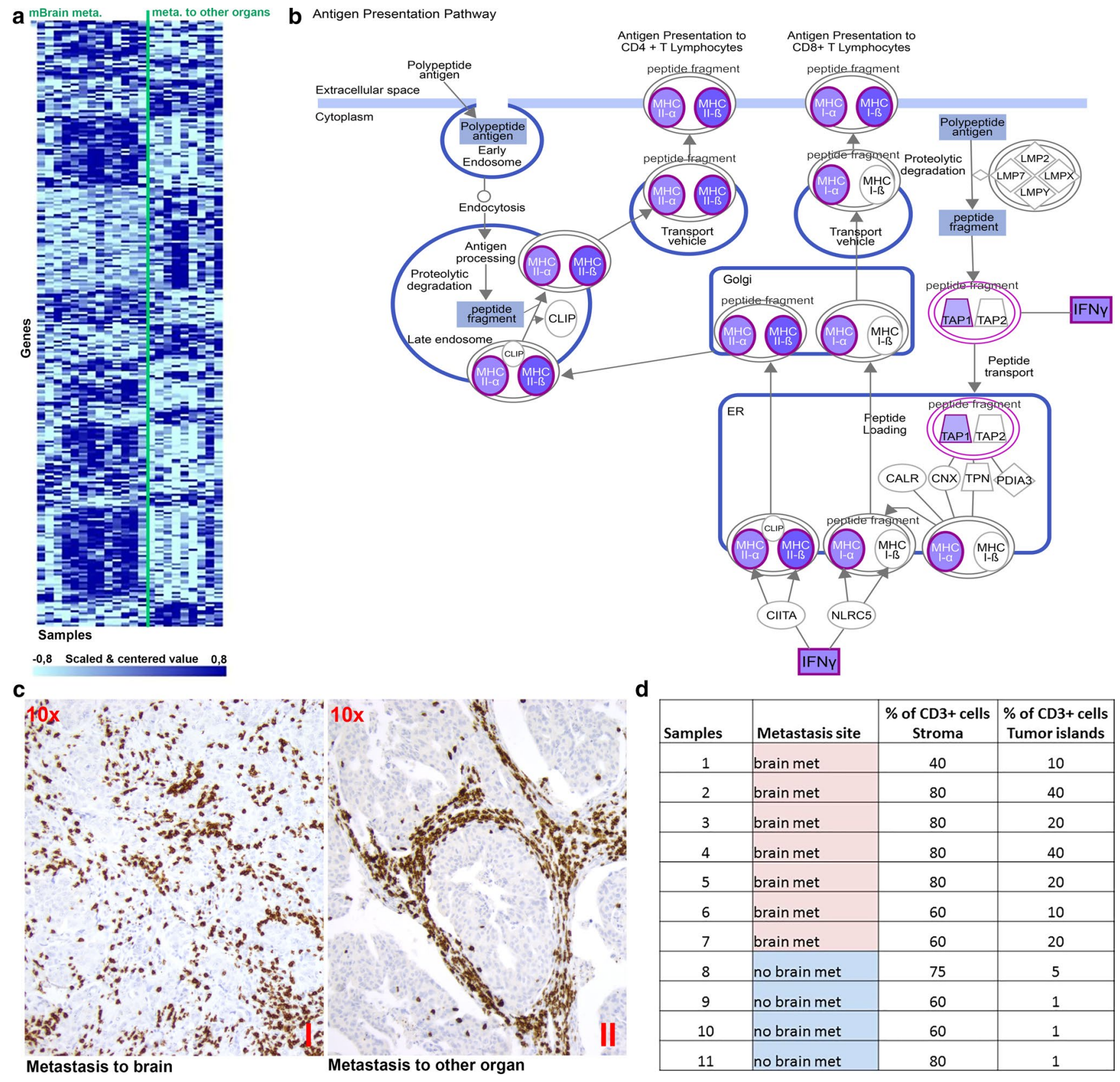

d
\begin{tabular}{|c|l|c|c|}
\hline Samples & Metastasis site & $\begin{array}{c}\% \text { of CD3+ cells } \\
\text { Stroma }\end{array}$ & $\begin{array}{c}\% \text { of CD3+ cells } \\
\text { Tumor islands }\end{array}$ \\
\hline 1 & brain met & 40 & 10 \\
\hline 2 & brain met & 80 & 40 \\
\hline 3 & brain met & 80 & 20 \\
\hline 4 & brain met & 80 & 40 \\
\hline 5 & brain met & 80 & 20 \\
\hline 6 & brain met & 60 & 10 \\
\hline 7 & brain met & 60 & 20 \\
\hline 8 & no brain met & 75 & 5 \\
\hline 9 & no brain met & 60 & 1 \\
\hline 10 & no brain met & 60 & 1 \\
\hline 11 & no brain met & 80 & 1 \\
\hline
\end{tabular}

Fig. 1 Breast cancer samples associated with brain metastasis express genes involved in the T lymphocyte response. a Heat map of the 298 differentially expressed probes between the primary breast cancer samples that developed metastases, with or without brain metastasis. b Pathway analysis revealed the involvement of the $\mathrm{T}$ cells response in the formation of brain metastasis. In this "Antigen Presenting Pathway", the up-regulated genes in the samples that developed brain metastasis are shown in purple. c (1) In the primary breast cancer samples associated with brain metastasis, $T$ cells invade the tumor tissue. (2) In the samples associated with metastasis to other sites, the $\mathrm{T}$ cells remain in the tumor stroma. (CD3, 100 $\times)$. d Percentages of TILs in the primary breast cancer samples of patients who developed metastasis to brain or to other organs

neither the $\mathrm{T}$ cells, nor their conditioned media, changed the permeability of the BBB (data not shown). We also tested a possible direct effect of interferon gamma (IFN $\gamma$ ) secreted by the $\mathrm{T}$ cells, on the tumor cells, by incubating the breast cancer cells with several concentrations of IFN $\gamma$, but no effect on the ability to cross the BBB model 
Table 2 Top ten canonical pathways (ingenuity)

\begin{tabular}{|c|c|c|c|}
\hline $\begin{array}{l}\text { Ingenuity Canonical } \\
\text { Pathways }\end{array}$ & $\log (p-v a l u e)$ & Ratio * & Genes \\
\hline $\begin{array}{l}\text { Communication between } \\
\text { Innate and Adaptive } \\
\text { Immune Cells }\end{array}$ & $1.65 \mathrm{E}-08$ & $9.82 \mathrm{E}-02$ & $\begin{array}{l}\text { CXCL10, IFNG, HLA-C, HLA-DRB3, TLR8, } \\
\text { CCL3L1/CCL3L3, CD83, CD8A, TLR9, HLA-DRB5, } \\
\text { TNFSF13B }\end{array}$ \\
\hline $\begin{array}{l}\text { Antigen Presentation } \\
\text { Pathway }\end{array}$ & $1.44 \mathrm{E}-06$ & $1.67 \mathrm{E}-01$ & $\begin{array}{l}\text { IFNG, HLA-DOA, HLA-DQB2, HLA-C, HLA-DRB3, } \\
\text { TAP1, HLA-DRB5 }\end{array}$ \\
\hline $\begin{array}{l}\text { Allograft Rejection } \\
\text { Signaling }\end{array}$ & $1.77 \mathrm{E}-06$ & $7.22 \mathrm{E}-02$ & $\begin{array}{l}\text { IFNG, PRF1, HLA-DOA, HLA-DQB2, HLA-C, HLA- } \\
\text { DRB3, HLA-DRB5 }\end{array}$ \\
\hline $\begin{array}{l}\text { Type I Diabetes Mellitus } \\
\text { Signaling }\end{array}$ & $4.71 \mathrm{E}-06$ & $8.26 \mathrm{E}-02$ & $\begin{array}{l}\text { CD247, IFNG, PRF1, HLA-DOA, HLA-C, IFNGR2, } \\
\text { STAT1, CASP8, CD3D, HLA-DRB5 }\end{array}$ \\
\hline $\begin{array}{l}\text { Pathogenesis of Multiple } \\
\text { Sclerosis }\end{array}$ & $4.92 \mathrm{E}-06$ & $4.00 \mathrm{E}-01$ & CXCL10, CXCL11, CXCL9, CXCR3 \\
\hline $\begin{array}{l}\text { T Helper Cell } \\
\text { Differentiation }\end{array}$ & $7.10 \mathrm{E}-06$ & $1.11 \mathrm{E}-01$ & $\begin{array}{l}\text { IFNG, HLA-DOA, IL12RB1, ICOS, IL10RA, IFNGR2, } \\
\text { STAT1, HLA-DRB5 }\end{array}$ \\
\hline OX40 Signaling Pathway & $9.83 \mathrm{E}-06$ & $7.22 \mathrm{E}-02$ & $\begin{array}{l}\text { CD247, HLA-DOA, HLA-DQB2, HLA-C, HLA-DRB3, } \\
\text { CD3D, HLA-DRB5 }\end{array}$ \\
\hline $\begin{array}{l}\text { Cytotoxic T Lymphocyte- } \\
\text { mediated Apoptosis of } \\
\text { Target Cells }\end{array}$ & $4.90 \mathrm{E}-05$ & $1.28 \mathrm{E}-01$ & CD247, PRF1, HLA-C, CASP8, CDd3D \\
\hline $\begin{array}{l}\text { Crosstalk between Dendritic } \\
\text { Cells and Natural Killer } \\
\text { Cells }\end{array}$ & $8.95 \mathrm{E}-05$ & $7.55 \mathrm{E}-02$ & $\begin{array}{l}\text { IFNG, PRF1, HLA-C, HLA-DRB3, CD83, TLR9, ITGAL, } \\
\text { HLA-DRB5 }\end{array}$ \\
\hline $\begin{array}{l}\text { Altered T Cell and B Cell } \\
\text { Signaling in Rheumatoid } \\
\text { Arthritis }\end{array}$ & $2.42 \mathrm{E}-04$ & $7.00 \mathrm{E}-02$ & $\begin{array}{l}\text { IFNG, HLA-DOA, CXCL13, TLR8, TLR9, HLA-DRB5, } \\
\text { TNFSF13B }\end{array}$ \\
\hline
\end{tabular}

Red: up-regulated, and green: down-regulated, in primary breast cancers samples associated with metastasis to brain

*Ratio of genes found over their total number in a particular pathway

Table 3 Top ten canonical pathways resulted from global testing

\begin{tabular}{lll}
\hline Global test canonical pathways & $\begin{array}{l}\text { Comparative } P \\
\text { value }\end{array}$ & $P$ value \\
\hline The 41BB-dependent immune response & 0.004 & 0.0016 \\
Chaperones modulate interferon signaling pathway & 0.004 & 0.0043 \\
Th1-Th2 differentiation & 0.008 & 0.0045 \\
Roles of arrest independent recruitment of Src Kinases in GPCR signaling & 0.012 & 0.0055 \\
X arrest ins in GPCR desensitization & 0.012 & 0.0101 \\
B lymphocyte cell surface molecules & 0.011 & 0.0117 \\
Role of Tob in T cell activation & 0.006 & 0.0118 \\
Dendritic cells in regulating TH1 and TH2 development & 0.009 & 0.0144 \\
Activation of Csk by cAMP dependent protein kinase inhibits signaling & 0.012 & 0.0180 \\
$\quad$ through the T cell receptor & & \\
NO2-dependent IL-12 pathway in NK cells & 0.015 & 0.0187 \\
\hline
\end{tabular}

*P value calculated by 1000 re-samplings was noticeable. In addition, we tested the effect of IL-2 (a required growth factor for culturing $\mathrm{T}$ lymphocytes) on tumor cells, but no facilitating effect was observed either (Fig. 2d). Both IFN $\gamma$ and IL-2 did not change the permeability of the BBB (data not shown). These experiments confirmed that $\mathrm{T}$ lymphocytes and their secreted factors increase the ability of breast cancer cells to cross the in vitro BBB model, and also proved that antigen-specific interaction between breast cancer cells and $\mathrm{T}$ lymphocytes is not necessary to promote the discovered facilitating effect.

\section{GBP1 protein is involved in changing the ability of breast cancer cells in crossing the BBB}

Next, we aimed to identify the changes that occur in breast cancer cells after co-culturing with $\mathrm{T}$ lymphocytes responsible for their increased capacity to pass through the BBB. Therefore, we measured the proteome of breast cancer cells before and after co-culturing with $\mathrm{T}$ cells by mass spectrometry. The proteomics comparisons lead to the identification of 21 differentially regulated proteins between the two groups (out of over 2500) at $P<0.05,12$ of which were 

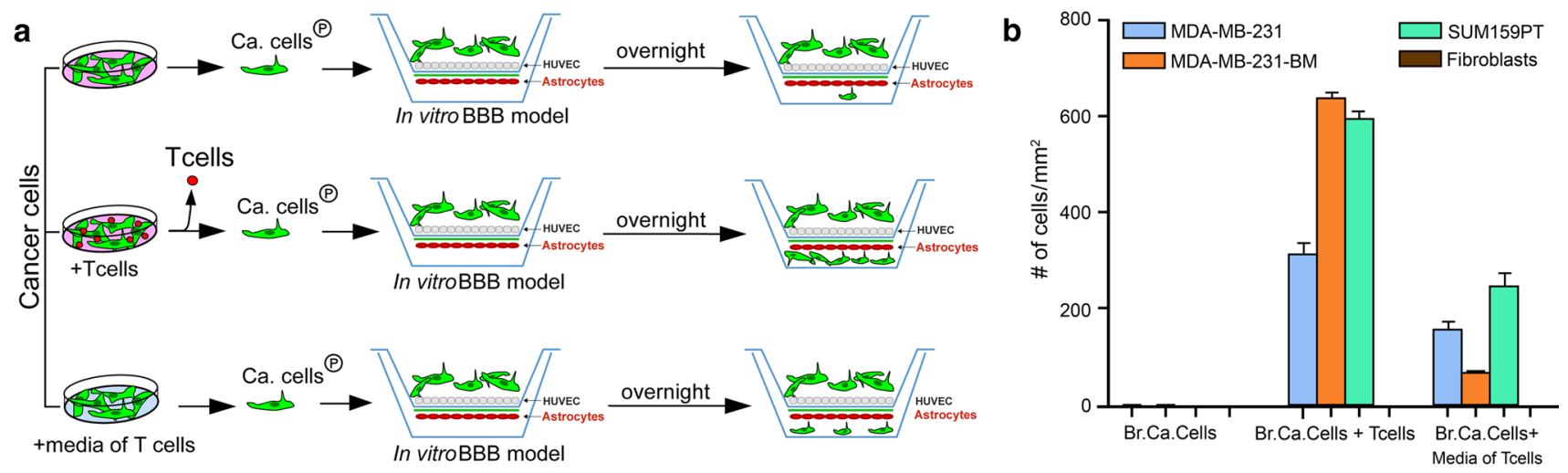

C

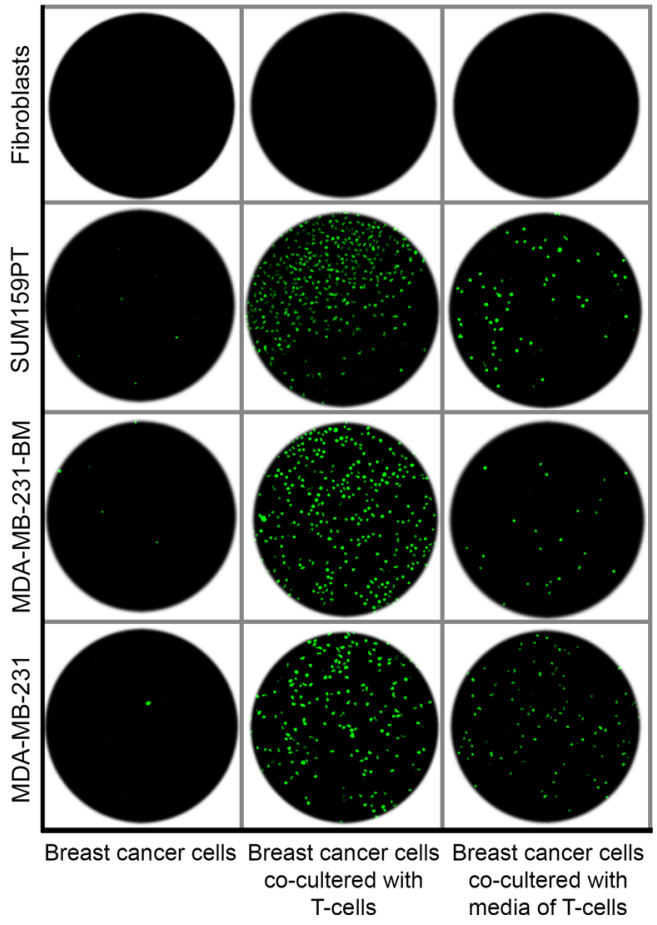

Fig. $2 \mathrm{~T}$ lymphocytes increase the ability of breast cancer cells to cross the BBB in the in vitro model. a Schema of experimental design. b Three breast cancer cell lines (MDA-MB-231, MDA-MB231-BM, and SUM159PT) showed a limited ability to cross the in vitro BBB (left column, lower three fields). Following co-culture with $\mathrm{T}$ cells, the ability of breast cancer cells to cross the BBB increased significantly (middle column, lower three fields). Conditioned media of $\mathrm{T}$ cells also increased the ability of breast cancer

up-regulated in the cells exposed to the T cells (Tables 4, $5)$. The 21 differentially regulated proteins were compared to the 298 differentially expressed genes identified in the mRNA gene expression arrays (Fig. 3a) and GBP1 was the only protein that matched at the mRNA level. GBP1 protein was exclusively measured and identified in all three breast cancer cell lines that were co-cultured with $\mathrm{T}$ lymphocytes $(P<0.001)$, and the $G B P 1$ gene was up-regulated in the primary breast cancer samples that developed brain metastasis d

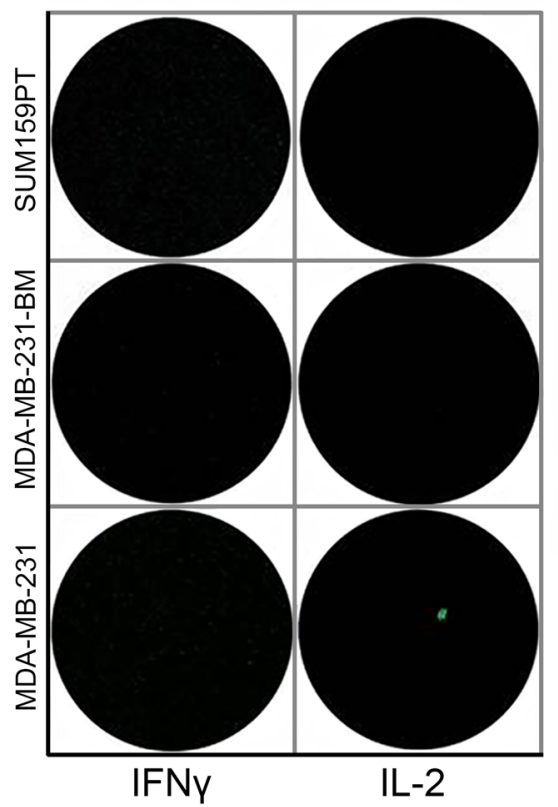

cells to cross the BBB, but to a lesser extent (right column, lower three fields). Neither T cells, nor their media, facilitated fibroblasts to cross the BBB (upper row). All experiments were repeated ten times. c Quantitative representation of B (error bars indicate standard deviation) $(\mathrm{Br}$. Ca. = breast cancer). $\mathbf{d}$ IFN $\gamma$ and IL-2 did not change the ability of breast cancer cells to cross the BBB. These experiments were repeated three times

( $P<0.05$ and 1.5 fold change). Furthermore, staining for GBP1 was positive only in the samples of the primary breast cancers of the patients who developed brain metastases, while not in the samples of patients who developed metastasis to other organs (Fig. 3b, c). Furthermore, the tumor areas with and without the expression of GBP1 were morphologically indistinguishable, except for the presence of TILs in the former. To further confirm our findings, we validated the upregulation of GBP1 after co-culturing breast cancer 


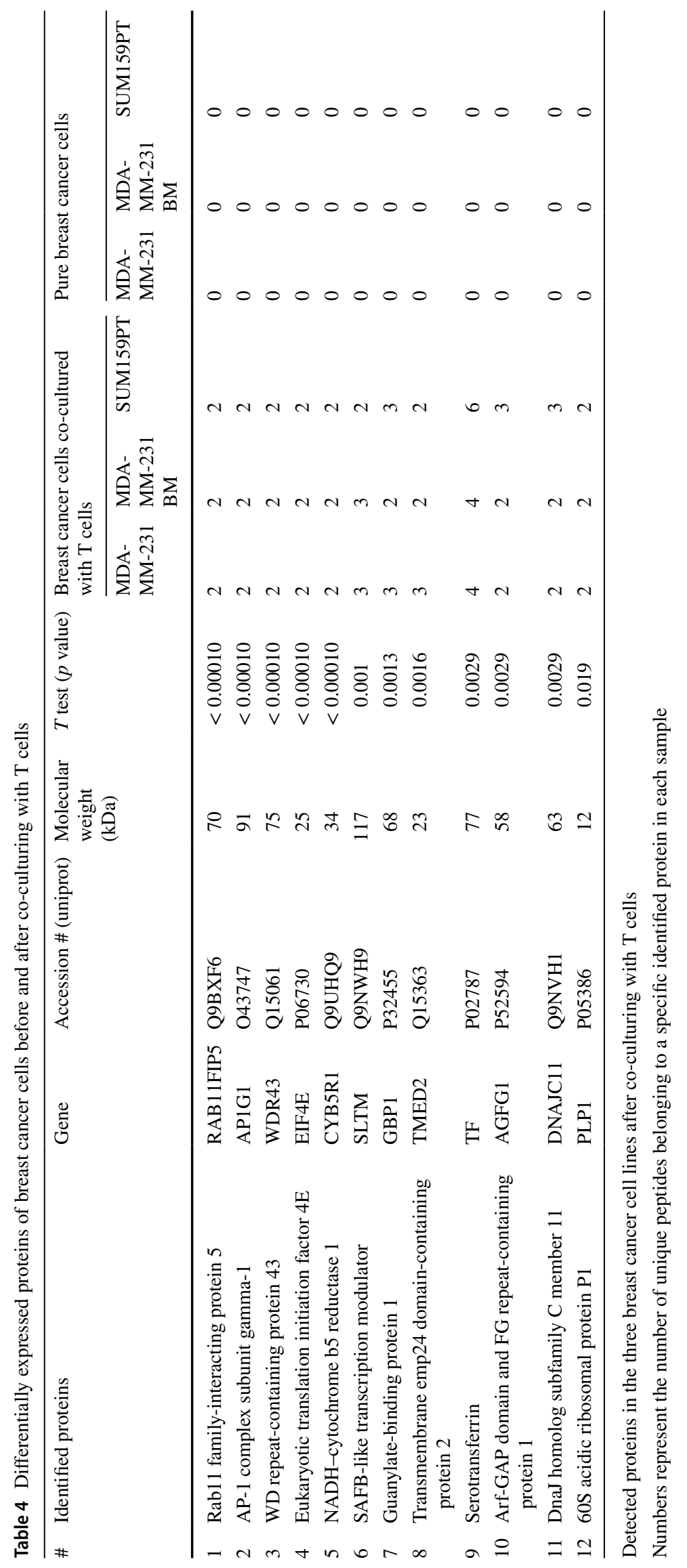




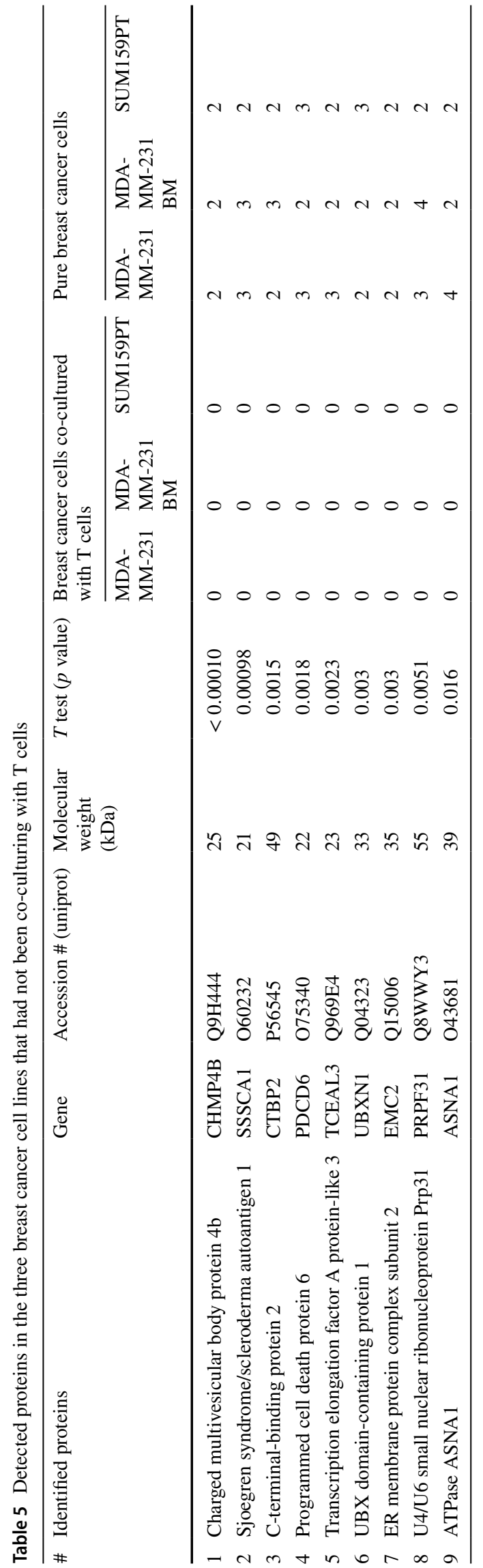

cells with T lymphocytes by RT-PCR (Fig. 3d). In addition, immunohistochemical staining for GBP1 of 20 independent samples of which 13 developed brain metastasis showed positivity only in the ER- breast cancer samples of patients who developed brain metastasis (Fig. 3e).

The prominent effect of $G B P 1$ on the capacity of tumor cells to cross the modelled BBB was examined by silencing experiments. GBP1 was silenced in MDA-MB-231 and in MDA-MB-231-BM breast cancer cell lines using pooled probes against $G B P 1$. However, the expression of $G B P 1$ was not affected when using siSham (negative control) (Fig. 4a). Subsequently, the cancer cells were co-cultured with T cells. The silenced $G B P I$ breast cancer cells showed a significant decrease in the ability to cross the BBB following co-cultured with $\mathrm{T}$ cells as compared to siSham cells, or to breast cancer cells that were not affected by silencing. A 30-70 fold decline in crossing of the BBB was reached following silencing of GBPl (Fig. 4b, c).

\section{T lymphocytes increase the ability of breast cancer cells to induce brain metastases in a mouse model}

To functionally test the ability of $\mathrm{T}$ cells to promote brain metastasis, we used a cancer cell line (ErbB2-P) established from a spontaneous ErbB2 + mammary tumor derived from MMTV driven-NeuNT transgenic mice [34]. This cell line does not have the ability to target the brain when injected in the systemic circulation [58]. The ErbB2-P cells were co-cultured with T cells, which were previously activated in vitro (Fig. 5a). Sorted cancer cells were initially interrogated by qRT-PCR to analyze Gbpl levels. Analysis of three independent experiments showed that co-culture of ErbB2-P with activated T cells induces a significant increase in $G b p l$ expression levels in the cancer cells (Fig. 5b). To interrogate the influence of $\mathrm{T}$ cells on metastasis, ErbB2-P cells were intracardially inoculated in immunocompetent syngeneic mice (Fig. 5a). 21 days after inoculation, most of the clones of the ErbB2-P cell line were not able to generate brain metastasis with only one animal out of $12(8.3 \%)$ showing bioluminescence in the brain (Fig. $5 \mathrm{c}, \mathrm{d}, \mathrm{f}, \mathrm{h}$ ). This limited potential to grow in the brain of the parental cell line dramatically increased when cancer cells inoculated had been previously in contact with $\mathrm{T}$ cells. Seven out of thirteen (53.8\%) animals inoculated with ErbB2-P cocultured with $\mathrm{T}$ cells developed brain metastasis (Fig. 5c, $\mathrm{d}, \mathrm{f}, \mathrm{h})$. This sixfold increase in the ability to generate secondary tumors in the brain was not mimicked in other organs since ex vivo analysis of lungs, liver, kidneys, adrenal glands, and bones (data not shown) did not show any difference nor in the percentage of animals affected (ErbB2-P: 25\% mice with extra-cranial disease; ErbB2$\mathrm{P}+\mathrm{T}$ cells: $33.3 \%$ ) neither in the bioluminescence signal 

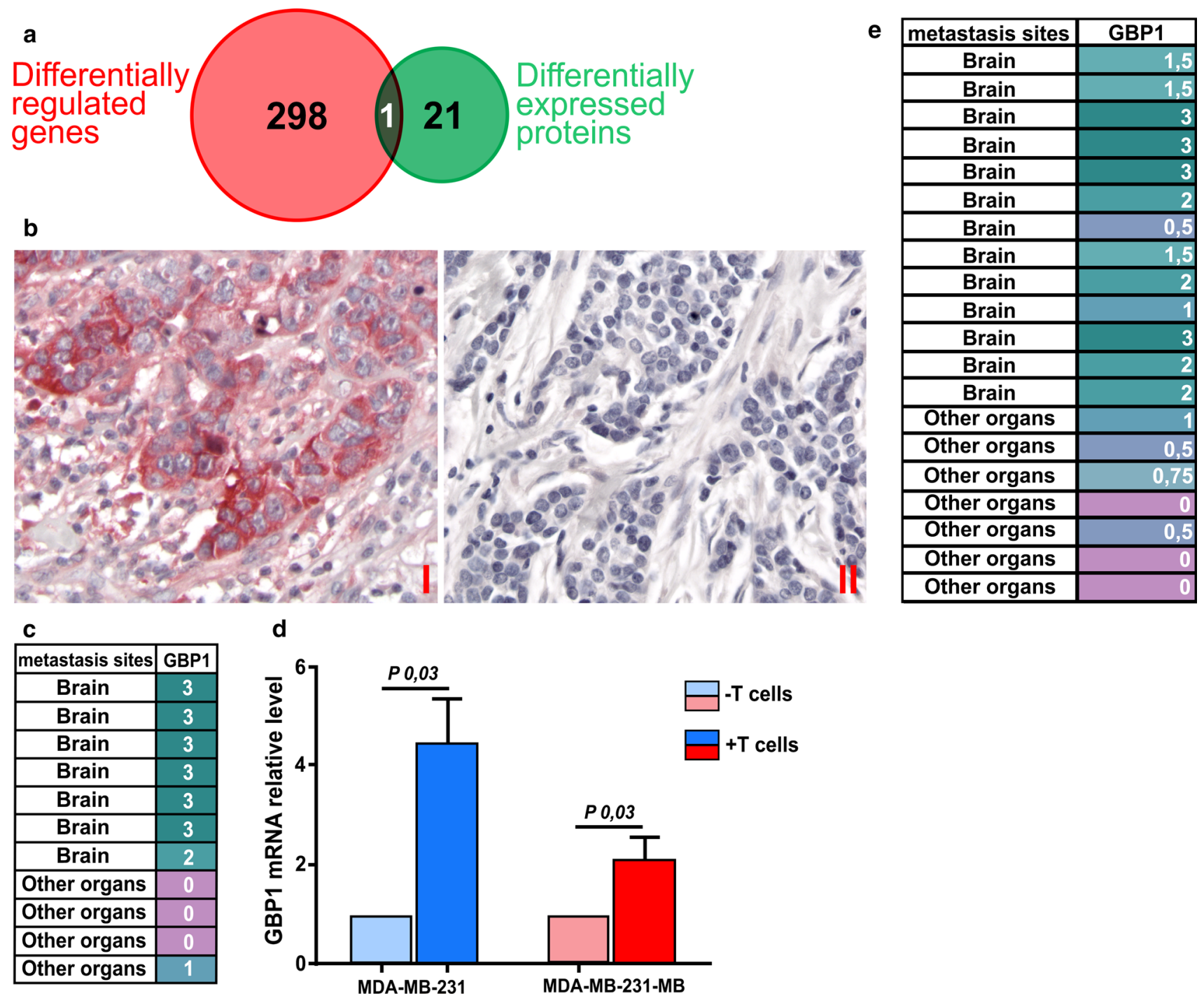

Fig. 3 Immunohistochemistry for GBP1 in primary breast cancer samples. a Venn diagram illustrating the overlap of differentially regulated genes and proteins. b (I) Expression of GBP1 protein in primary breast cancers with brain metastasis. (II) GBP1 protein in primary breast cancers with metastases to organs other than brain. $\mathbf{c}$ Semi-quantitative results of immunohistochemistry for GBP1 using the discovery sample set. The color scale represents the scores of the immunohistochemical staining, ranging from $0=$ no expression to 3 = highest expression. d RT-PCR results of the GBP1 expression in

from ex vivo analysis (Fig. 5e, g, i). We conclude that activated $\mathrm{T}$ cells are sufficient to increase the ability of breast cancer cells to develop brain metastasis. To investigate the brain metastatic phenotype in more detail, in particular if there was increased access of cancer cell clones in the brain parenchyma, or if there is also an increased ability to colonize the brain, we microscopically examined the brains. Most brains inoculated with ErbB2-P cells did not show any cancer cell, even at the single cell level with the exception of the BLI + one (Fig. 5j, k).
MDA-MB-231 and MDA-MB-231-BM before and after co-culturing with $\mathrm{T}$ lymphocytes. For both cell lines, the GBP1 expression before and after co-culturing with $\mathrm{T}$ cells differ significantly. Bars indicate mean values \pm SEM, from three independent experiments. e Semiquantitative results of immunohistochemistry for GBP1 using 20 independent primary breast cancer samples. The color scale represents the scores of the immunohistochemical staining, ranging from $0=$ no expression to $3=$ highest expression

The ErbB2-P cells that were co-cultured with T cells consistently showed multiple cancer cell clones within the perivascular spaces (indicative of the ability to get access to the brain parenchyma; Fig. $5 \mathrm{j}, \mathrm{k}$ ), suggesting an increased ability to cross the BBB. In addition, increased size and invasive fronts at the metastatic deposits was observed, indicative of increased capability of parenchyma invasion (Fig. 51, m, in comparison with Fig. 5n, o). This observation suggests an additional influence of $\mathrm{T}$ cells providing cancer cells with further capabilities to 


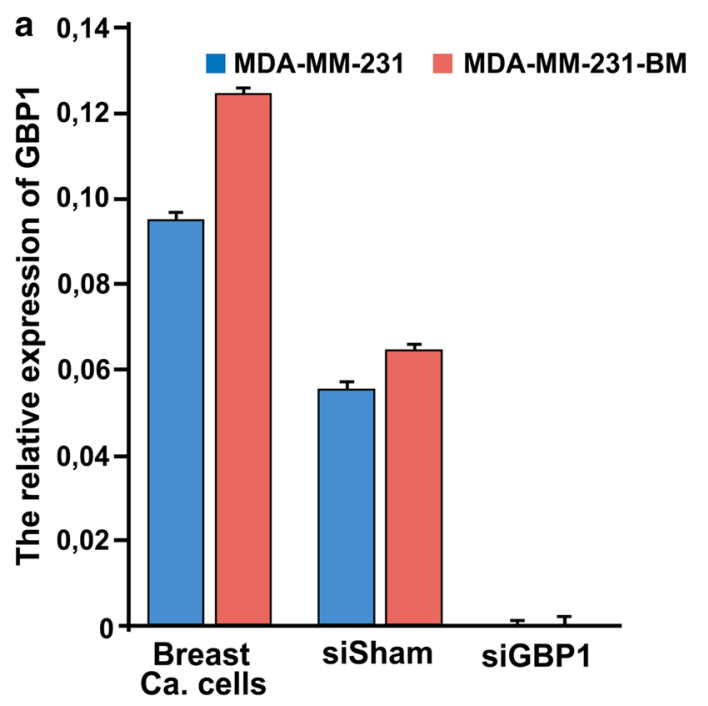

b

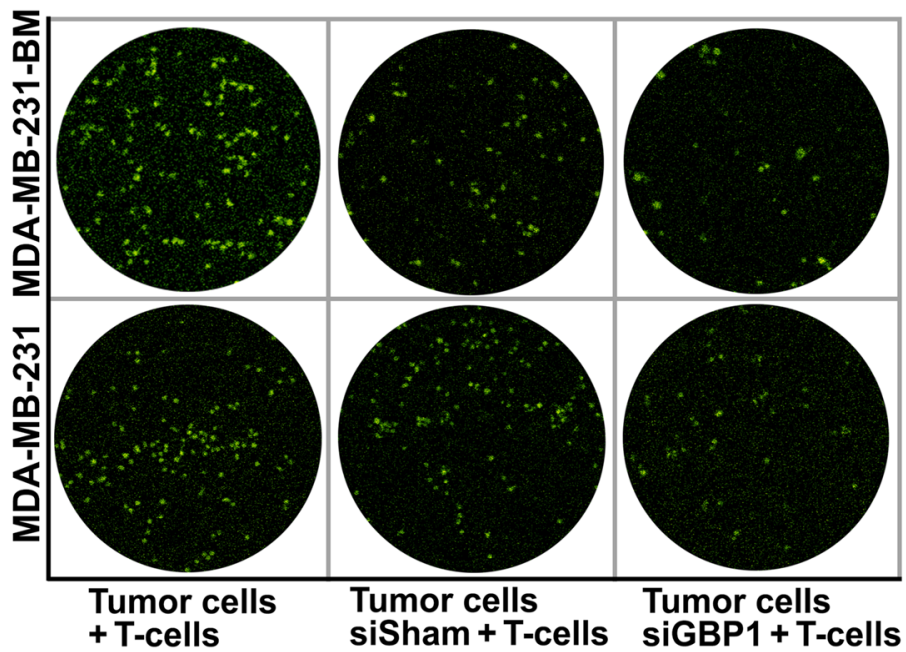

C

d
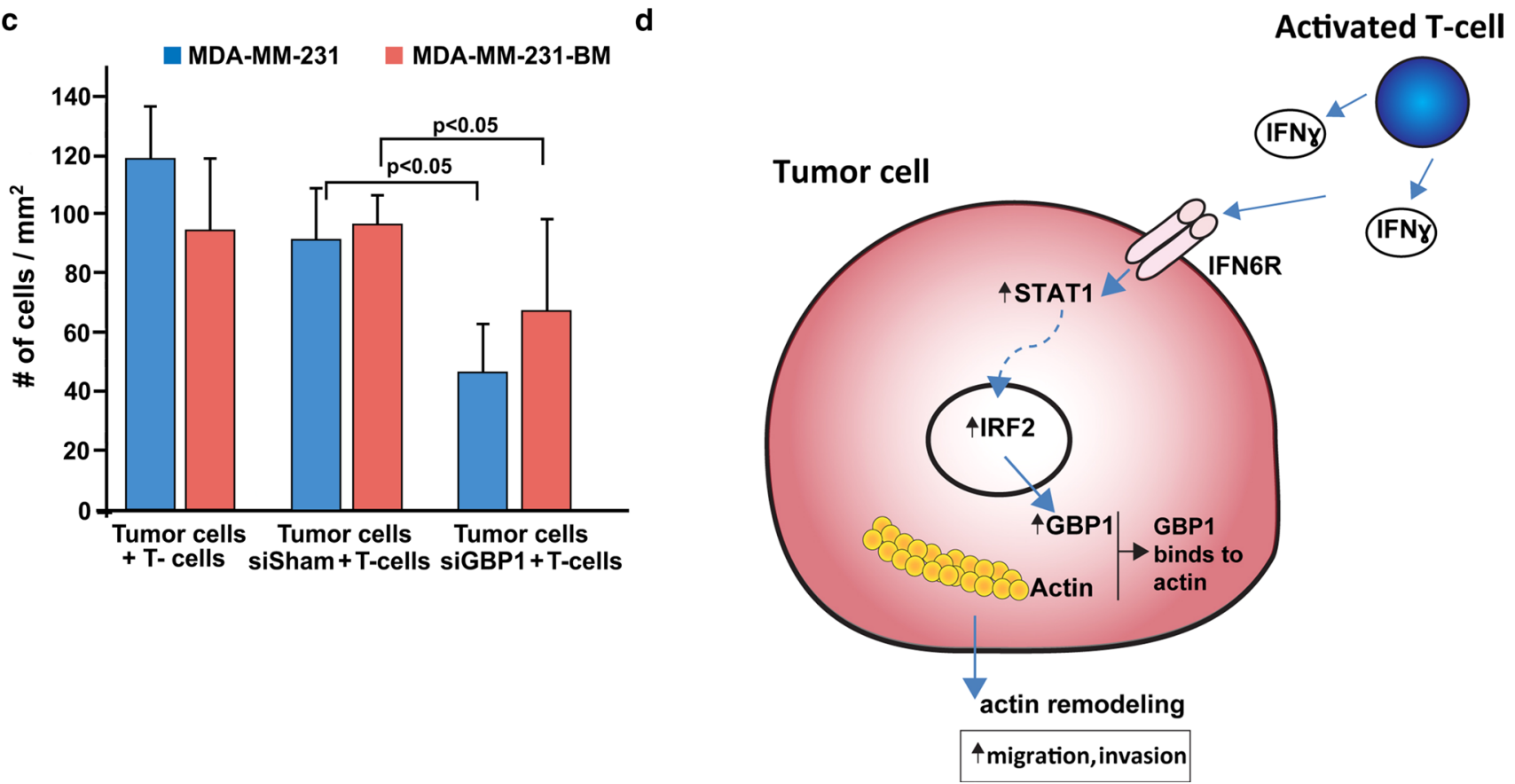

Fig. 4 GBP1 affects crossing of breast cancer cells through the BBB. a RT-PCR results of $G B P 1$ expression showing successful silencing. The expression of GBP1 in breast cancer cells was compared to that of the non-targeting siRNA (siSham) $(n=3$; bars indicate standard deviation). These experiments were repeated twice, and the results were reproducible. b Breast cancer cells silenced for $G B P 1$ and cocultured with $T$ cells show a reduction in their ability to pass the BBB (right column) as compared to the breast cancer cells that were

silenced for siSham (middle column). As a control, breast cancer cells not silenced for $G B P 1$, were co-cultured with $\mathrm{T}$ cells, showed their ability to cross the BBB (left column). These experiments were repeated twice, and the results were reproducible. c Quantitative results of $\mathrm{B}$; error bars indicate standard deviation). The number of breast cancer cells that were able to cross the BBB had decreased significantly after silencing $G B P 1$. d Cartoon illustrating the function of GBP1

advance from the first extravasation compartment. We conclude that the influence of the $T$ cells extends beyond making the breast cancer cells pass the BBB, but also makes them invade the brain tissue.

\section{Discussion}

The identification of the mechanisms and underlying molecular pathways that cancer cells use to cross the $\mathrm{BBB}$ is important for the development of strategies to 
prevent cerebral dissemination. In this study, we found the $\mathrm{T}$ lymphocyte response most prominently involved in the formation of cerebral metastases of ER- breast cancer patients. The involvement of T lymphocytes in the metastatic potential of breast cancer has been noticed previously, particularly implicating induction of immune tolerance by regulatory $\mathrm{T}$ lymphocytes $[2,5,33,39]$. The present results, however, reveal an entirely different effect of $\mathrm{T}$ cells, namely, that $\mathrm{T}$ lymphocytes and their secreted factors change the expressional profiles of tumor cells, thereby increasing their ability to cross the BBB. It is known that the immune system mediates primary tumors in their proliferation and invasion by secretion of inflammatory cytokines, chemokines, autoantibodies, proteases, and more. The role of the immune system in the formation of metastases is complex and far from understood [1, 8, 28, 31]. To some extent, the present findings are reminiscent of the $\mathrm{T}$ cell involvement inducing receptor activator of nuclear factor- $\mathrm{KB}$ (RANK) signaling causing pulmonary metastases in a mouse breast cancer model [56]. However, the results obtained using human breast cancer samples show that the presence of $\mathrm{T}$ cells correlates with the formation of cerebral metastasis. This finding has not been reported previously.

The discovery of $\mathrm{T}$ cell involvement in the formation of cerebral metastasis was based on a relatively small series of samples of breast cancer patients. Therefore, we confirmed our findings at the functional level using in vivo and in vitro models. Injecting mice with breast cancer cells that were co-cultured with $\mathrm{T}$ cells proved that $\mathrm{T}$ cells play an important role in increasing the ability of breast cancer cells to cross the BBB and to develop brain metastasis. Interestingly, co-culturing breast cancer and $\mathrm{T}$ cells did not increase the tendency to metastasis to organs other than brain. The in vitro BBB model we used is composed of human endothelial cells and astrocytes, closely reflecting the normal barrier function of human $\mathrm{BBB}$. The ability of breast cancer cells to cross the BBB improved significantly when the tumor cells were co-cultured with $\mathrm{T}$ cells. The facilitating effect was observed after co-culturing with $\mathrm{T}$ cells isolated from normal donors as well as with antigen-specific T cells, indicative of antigen independency. Incubation of the breast cancer cells with the conditioned media of the $\mathrm{T}$ cells showed similar results, pointing to the importance of particular factors secreted by $\mathrm{T}$ lymphocytes. In an effort to identify the factors that caused the facilitating effect, we incubated breast cancer cell with IFN $\gamma$ that is secreted almost exclusively by $\mathrm{T}$ cells. Interestingly, IFN $\gamma$ did not change the ability of breast cancer cells to cross the BBB, nor did it change the permeability of the BBB itself. Similar results were obtained when incubating breast cancer cells with IL-2 . It could be argued that instead of single proteins, several secreted proteins and cytokines are necessary to induce the facilitating effect. The complex interplay between $\mathrm{T}$ cells and the humoral immune system was demonstrated in the MMTV-PyMT mouse model, where IL-4-expressing $\mathrm{CD} 4+\mathrm{T}$ lymphocytes indirectly promote invasion and subsequent metastasis of mammary adenocarcinomas [8]. In another mouse breast cancer model, the effects of interleukin (IL)- $1 \beta$ on the IL-17 expression of gamma delta $(\gamma \delta) \mathrm{T}$ cells were shown, affecting neutrophils and suppression of $\mathrm{CD} 8+\mathrm{T}$ cells, also leading to the formation of metastases [7].

Among the 21 differentially expressed proteins in the three breast cancer cell lines following co-culturing with $\mathrm{T}$ cells, only the $G B P 1$ gene was found to be overexpressed in the set of primary breast cancer samples that developed brain metastasis. RT-PCR results confirmed that GBP1 expression is significantly upregulated in breast cancer cells after co-culturing with $\mathrm{T}$ lymphocytes. Further confirmation of the expression of GBP1 was confirmed by immunohistochemistry in the discovery sample set and in an additional 20 independent samples. GBP1 positive cells were detected in tumor areas, where $\mathrm{T}$ lymphocytes invaded from the stroma in between the tumor cells. Human GBP1 is a secreted GTPase that is induced by IFN $\gamma$ and mediate the antibacterial and antiviral activities of IFN $\gamma$ [41]. The GBP1 protein binds to actin and plays a role in the remodeling of the fibrous actin structure thereby influencing cellular motility [14, 23, 41]. The regulation of the cytoskeleton and the remodeling of actin by GBP1 is of a great relevance in process like migration, invasion, proliferation and defense against barrier function, a possible link with the increased passage through the BBB $[22,41,46]$. However, the relation with brain invasion seems more complex since GBP1-mediated actin remodeling also contributes to the regulation of the innate and adaptive immune defense [41]. Moreover, mutations in the $G B P 1$ gene are among those related to the tumorigenesis of breast cancer [20] and the aggressive hormone-negative inflammatory subtype in particular [25]. In vitro studies revealed a role of GBPl in tamoxifen resistance [12]. The GBP1 protein is also involved in resistance to docetaxelis of prostate cancer [10], and in a recent study, it was shown that it is one of the key molecules contributing to cancer radioresistance [15]. With respect to tumors other than breast cancer, GBPl is considered to act as tumor suppressor gene in colorectal cancer [4], and as an effector of EGFR-driven tumor cell invasion in glioblastomas [27]. In addition, GBP1 was found to promote lymph node metastasis in esophageal squamosal cell carcinoma [26]. So far, GBP1 was not associated with brain metastasis of breast cancer. However, a recent study showed that the overexpression of GBP1 protein among others was associated with metastasis in TNBC [42]. Obviously, its expression 
a

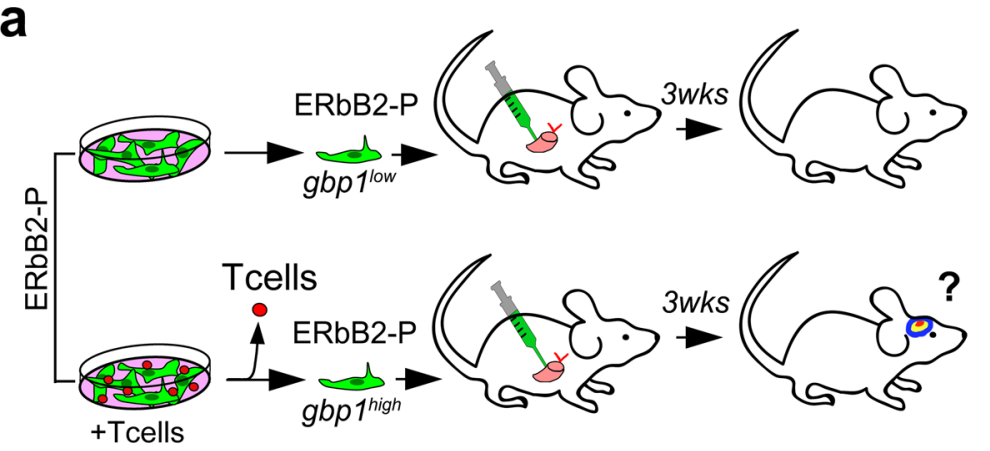

C

C $\quad$ ERbB2-P

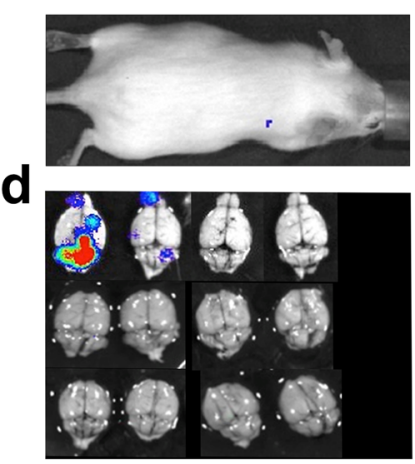

ERbB2-P + T-cells
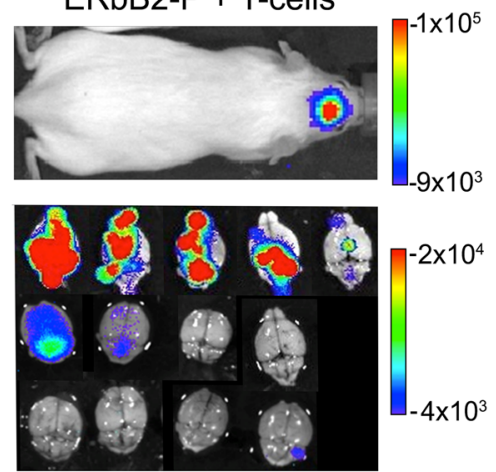

b

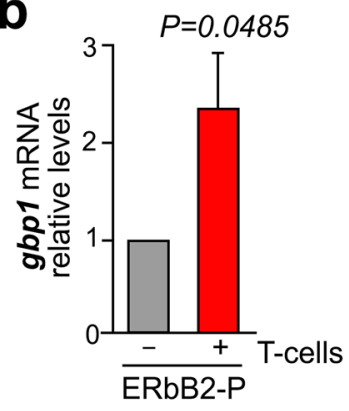

e
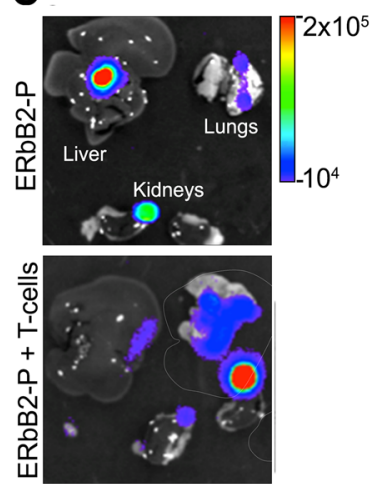

i
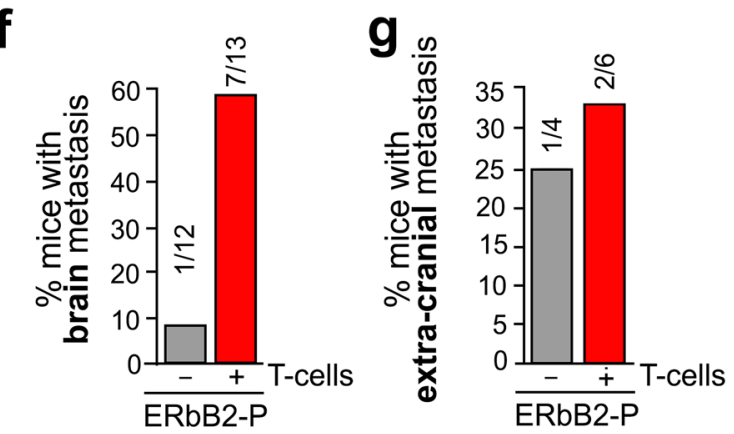

h
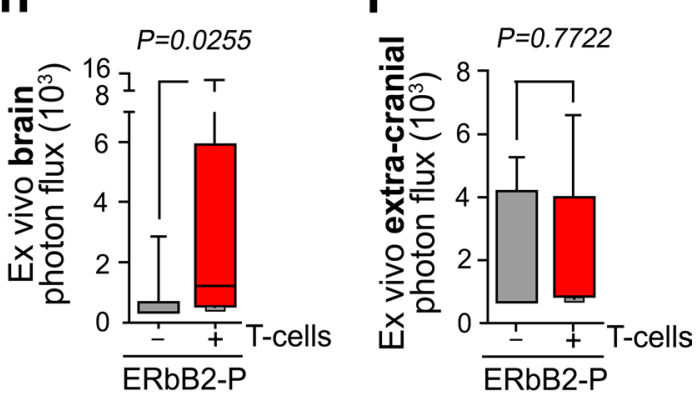

j ERbB2-P + T-cells $\mathbf{k}$

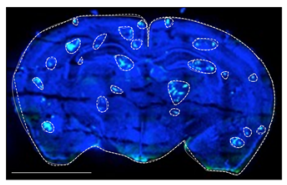

$\square$ ERbB2-P

$\square$ ERbB2-P + T-cells
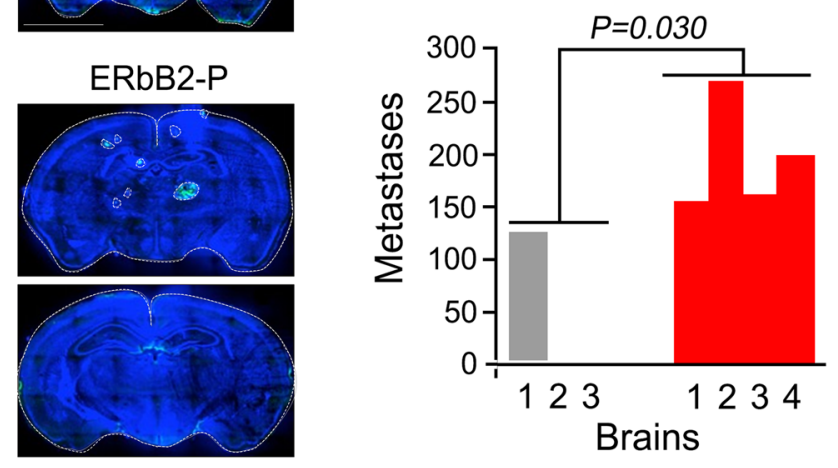

GFP DAPI
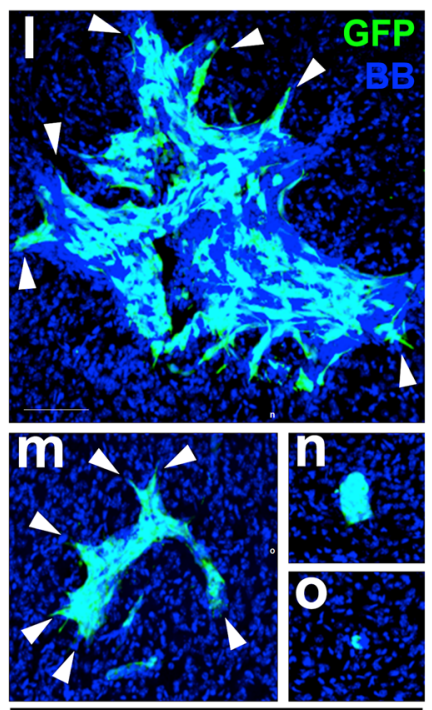

ERbB2-P + T-cells 
4Fig. $5 \mathrm{~T}$ lymphocytes facilitate brain metastasis of breast cancer in mice. a Schema of experimental design. b qRT-PCR of sorted ErbB2$\mathrm{P}$ cells after being co-cultured with $\mathrm{T}$ cells. Values indicate mean values \pm SEM, from three independent experiments. c Representative bioluminescence images (BLI) from mice 21 days after intracardiac injection. d Ex vivo BLI of brains from injected animals. e Representative BLI of extra-cranial metastases. f Graph showing the percentage of mice affected with brain metastasis. Numbers in bars indicate the absolute values g. Graph showing the percentage of mice affected with extra-cranial metastases. Numbers in bars indicate the absolute values. g Quantification of bioluminescence signal emitted by brains ex vivo. Error bars, minimum and maximum values reached by brains. Line in each bar indicates mean BLI value. $(n=12$ brains, ErbB2-P; 13 brains, ErbB2-P previously co-cultured with $\mathrm{T}$ cells (ErbB2-P $+\mathrm{T}$ cells), from 2 independent experiments. $P$ value is calculated using two-tailed $t$ test. h Quantification of bioluminescence signal emitted by extra-cranial metastases (liver, lungs and kidneys) ex vivo. Error bars, minimum and maximum values reached. Line in each bar indicates mean BLI value. $(n=4$ mice, ErbB2-P; 6 mice, ErbB2-P $+\mathrm{T}$ cells, from one experiment. $P$ value is calculated using two-tailed $t$ test. i Confocal scans of representative slices from different brains. Two brains from mice previously inoculated with ErbB2-P are shown to illustrate the limited seeding (upper panel) and complete absence (lower panel) of metastatic cells. Scale bar $300 \mathrm{~mm}$. White line demarcates brain slices. Dotted white line surrounds gfp + metastases. $\mathbf{j}$ Quantification of mean number of metastases in representative brains from each condition. Individual brains are plotted in each experimental condition ( $n=3$ brains from ErbB2$\mathrm{P}$ injected mice; 4 brains from ErbB2-P $+\mathrm{T}$ cells injected mice). $P$ value is calculated using two-tailed $t$ test. $\mathbf{k} \mathrm{L}-\mathrm{O}$. Representative images to show the heterogeneity present in brains from mice injected with ErbB2-P $+\mathrm{T}$ cells. (1-m) Large and medium size metastases with invasive fronts (arrows) co-exist with less abundant (n) wellcircumscribed metastases and (o) abundant single cell events. Scale bar $75 \mu \mathrm{m}$

sites, specific action, and possible partners involved in brain metastasis need further exploration. Most importantly, investigations in the effects of blocking its expression in vivo are needed to develop therapeutic strategies in preventing metastases to brain.

Our results highlight the importance of T lymphocytes and their secreted cytokines for the formation of brain metastasis originating from ER- breast cancers. This is new to current knowledge of the complex interplay between $\mathrm{T}$ lymphocytes and cancer cells. T lymphocytes change the expressional repertoire of breast cancer cells that promotes their ability to cross the BBB. At this point, subsequent studies are necessary to detail the role of any specific $\mathrm{T}$ cell subset in facilitating the breast cancers to cross the BBB. The up-regulation of the $G B P 1$ gene and the over-expression of GBP1 protein seem to be crucial to this effect. The predictive value of this protein of the rise of cerebral metastases should be evaluated in prospective settings.

Acknowledgements The authors would like to thank Prof. Dr. Joan Massague for sharing the MDA-MB-231-MB cell line, Dr. Lennard Dekker for his assistance in proteomics measurements, Mrs. Mandy van Brakel for her additional help in obtaining the T lymphocytes and Mr. Frank van der Panne for his help in arranging the figures. In addition, the authors would like to thank Dr. W.K. Cavenee and Dr. P.S. Mischel for their critical comments on this work.

Author contributions DAMM, RMSM, and JMK designed and carried out most experiments, prepared figures and tables, and wrote the manuscript. AMS, VW, JWMM, and JAF provided the expression arrays of the breast cancers; RD and $\mathrm{CB}$ provided the $\mathrm{T}$ cells and culture media for T cells; LZ and TML performed the proteomic analyses; MS and ALN assisted with data analysis; MW and provided technical assistance with IHC; NP and MV provided all of the mouse model work.

Funding J.M.K. received funding for this work by the Dutch Cancer Society (KWF) (EMCR 2009-4553). M.V. was supported by Beug Foundation's Prize for Metastasis Research 2017 (M.V.).

\section{Compliance with ethical standards}

Conflict of interest The authors declare that they have no conflict of interest.

Open Access This article is distributed under the terms of the Creative Commons Attribution 4.0 International License (http://creativecomm ons.org/licenses/by/4.0/), which permits unrestricted use, distribution, and reproduction in any medium, provided you give appropriate credit to the original author(s) and the source, provide a link to the Creative Commons license, and indicate if changes were made.

\section{References}

1. Aspord C, Pedroza-Gonzalez A, Gallegos M, Tindle S, Burton EC, Su D, Marches F, Banchereau J, Palucka AK (2007) Breast cancer instructs dendritic cells to prime interleukin 13-secreting CD4+ T cells that facilitate tumor development. J Exp Med 204:1037-1047. https://doi.org/10.1084/jem.20061120

2. Bohling SD, Allison KH (2008) Immunosuppressive regulatory $\mathrm{T}$ cells are associated with aggressive breast cancer phenotypes: a potential therapeutic target. Mod Pathol 21:1527-1532. https:// doi.org/10.1038/modpathol.2008.160

3. Bos PD, Zhang XH, Nadal C, Shu W, Gomis RR, Nguyen DX, Minn AJ, van de Vijver MJ, Gerald WL, Foekens JA et al (2009) Genes that mediate breast cancer metastasis to the brain. Nature 459:1005-1009. https://doi.org/10.1038/nature08021

4. Britzen-Laurent N, Lipnik K, Ocker M, Naschberger E, Schellerer VS, Croner RS, Vieth M, Waldner M, Steinberg P, Hohenadl C et al (2013) GBP-1 acts as a tumor suppressor in colorectal cancer cells. Carcinogenesis 34:153-162. https://doi.org/10.1093/carcin/ bgs 310

5. Carvalho MI, Pires I, Prada J, Queiroga FL (2014) A role for T-lymphocytes in human breast cancer and in canine mammary tumors. Biomed Res Int 2014:130894. https://doi.org/10.1155 /2014/130894

6. Chiu WT, Lee HT, Huang FJ, Aldape KD, Yao J, Steeg PS, Chou CY, Lu Z, Xie K, Huang S (2011) Caveolin-1 upregulation mediates suppression of primary breast tumor growth and brain metastases by stat 3 inhibition. Cancer Res 71:4932-4943. https://doi. org/10.1158/0008-5472.CAN-10-4249

7. Coffelt SB, Kersten K, Doornebal CW, Weiden J, Vrijland K, Hau CS, Verstegen NJ, Ciampricotti M, Hawinkels LJ, Jonkers J et al (2015) IL-17-producing gammadelta T cells and neutrophils 
conspire to promote breast cancer metastasis. Nature 522:345348. https://doi.org/10.1038/nature14282

8. DeNardo DG, Coussens LM (2007) Inflammation and breast cancer. Balancing immune response: crosstalk between adaptive and innate immune cells during breast cancer progression. Breast Cancer Res 9:212. https://doi.org/10.1186/bcr1746

9. Dennis G Jr, Sherman BT, Hosack DA, Yang J, Gao W, Lane HC, Lempicki RA (2003) DAVID: database for annotation, visualization, and integrated discovery. Genome Biol 4:P3

10. Desarnaud F, Geck P, Parkin C, Carpinito G, Makarovskiy AN (2011) Gene expression profiling of the androgen independent prostate cancer cells demonstrates complex mechanisms mediating resistance to docetaxel. Cancer Biol Ther 11:204-212

11. Du P, Kibbe WA, Lin SM (2008) lumi: a pipeline for processing Illumina microarray. Bioinformatics 24:1547-1548. https://doi. org/10.1093/bioinformatics/btn224

12. Elias D, Vever H, Laenkholm AV, Gjerstorff MF, Yde CW, Lykkesfeldt AE, Ditzel HJ (2015) Gene expression profiling identifies FYN as an important molecule in tamoxifen resistance and a predictor of early recurrence in patients treated with endocrine therapy. Oncogene 34:1919-1927. https://doi.org/10.1038/ onc. 2014.138

13. Eugenin EA, Berman JW (2003) Chemokine-dependent mechanisms of leukocyte trafficking across a model of the blood-brain barrier. Methods 29:351-361

14. Forster F, Paster W, Supper V, Schatzlmaier P, Sunzenauer S, Ostler N, Saliba A, Eckerstorfer P, Britzen-Laurent N, Schutz G et al (2014) Guanylate binding protein 1-mediated interaction of $\mathrm{T}$ cell antigen receptor signaling with the cytoskeleton. J Immunol 192:771-781. https://doi.org/10.4049/jimmunol.1300377

15. Fukumoto M, Amanuma T, Kuwahara Y, Shimura T, Suzuki M, Mori S, Kumamoto H, Saito Y, Ohkubo Y, Duan Z et al (2014) Guanine nucleotide-binding protein 1 is one of the key molecules contributing to cancer cell radioresistance. Cancer Sci 105:13511359. https://doi.org/10.1111/cas.12489

16. Goeman JJ, van de Geer SA, de Kort F, van Houwelingen HC (2004) A global test for groups of genes: testing association with a clinical outcome. Bioinformatics 20:93-99

17. Harrell JC, Prat A, Parker JS, Fan C, He X, Carey L, Anders C, Ewend M, Perou CM (2012) Genomic analysis identifies unique signatures predictive of brain, lung, and liver relapse. Breast Cancer Res Treat 132:523-535. https://doi.org/10.1007/s10549-0111619-7

18. Heitz F, Harter P, Lueck HJ, Fissler-Eckhoff A, Lorenz-Salehi F, Scheil-Bertram S, Traut A, du Bois A (2009) Triple-negative and HER2-overexpressing breast cancers exhibit an elevated risk and an earlier occurrence of cerebral metastases. Eur J Cancer 45:2792-2798. https://doi.org/10.1016/j.ejca.2009.06.027

19. Hollestelle A, Nagel JH, Smid M, Lam S, Elstrodt F, Wasielewski M, Ng SS, French PJ, Peeters JK, Rozendaal MJ et al (2010) Distinct gene mutation profiles among luminal-type and basal-type breast cancer cell lines. Breast Cancer Res Treat 121:53-64. http s://doi.org/10.1007/s10549-009-0460-8

20. Horvath A, Pakala SB, Mudvari P, Reddy SD, Ohshiro K, Casimiro S, Pires R, Fuqua SA, Toi M, Costa L et al (2013) Novel insights into breast cancer genetic variance through RNA sequencing. Sci Rep 3:2256. https://doi.org/10.1038/srep02256

21. da Huang W, Sherman BT, Lempicki RA (2009) Systematic and integrative analysis of large gene lists using DAVID bioinformatics resources. Nat Protoc 4:44-57. https://doi.org/10.1038/npro t.2008.211

22. Ivanov AI, Parkos CA, Nusrat A (2010) Cytoskeletal regulation of epithelial barrier function during inflammation. Am J Pathol 177:512-524. https://doi.org/10.2353/ajpath.2010.100168

23. Kim BH, Chee JD, Bradfield CJ, Park ES, Kumar P, MacMicking JD (2016) Interferon-induced guanylate-binding proteins in inflammasome activation and host defense. Nature Immunol 17:481-489. https://doi.org/10.1038/ni.3440

24. Lamers $\mathrm{CH}$, Willemsen RA, van Elzakker P, van Krimpen BA, Gratama JW, Debets R (2006) Phoenix-ampho outperforms PG13 as retroviral packaging cells to transduce human T cells with tumor-specific receptors: implications for clinical immunogene therapy of cancer. Cancer Gene Ther 13:503-509. http s://doi.org/10.1038/sj.cgt.7700916

25. Lerebours F, Vacher S, Andrieu C, Espie M, Marty M, Lidereau $\mathrm{R}$, Bieche I (2008) NF-kappa B genes have a major role in inflammatory breast cancer. BMC Cancer 8:41. https://doi. org/10.1186/1471-2407-8-41

26. Li L, Ma G, Jing C, Liu Z (2015) Guanylate-binding protein 1 (GBP1) promotes lymph node metastasis in human esophageal squamous cell carcinoma. Discov Med 20:369-378

27. Li M, Mukasa A, Inda MM, Zhang J, Chin L, Cavenee W, Furnari F (2011) Guanylate binding protein 1 is a novel effector of EGFR-driven invasion in glioblastoma. J Exp Med 208:26572673. https://doi.org/10.1084/jem.20111102

28. Lin EY, Pollard JW (2004) Macrophages: modulators of breast cancer progression. Novartis Found Symp 256:158-168 (discussion 168-172, 259-169)

29. Lin NU, Claus E, Sohl J, Razzak AR, Arnaout A, Winer EP (2008) Sites of distant recurrence and clinical outcomes in patients with metastatic triple-negative breast cancer: high incidence of central nervous system metastases. Cancer 113:26382645. https://doi.org/10.1002/cncr.23930

30. Lin NU, Winer EP (2007) Brain metastases: the HER2 paradigm. Clin Cancer Res 13:1648-1655. https://doi.org/10.1158 /1078-0432.CCR-06-2478

31. Liu W, Vivian CJ, Brinker AE, Hampton KR, Lianidou E, Welch DR (2014) Microenvironmental influences on metastasis suppressor expression and function during a metastatic cell's journey. Cancer Microenviron. https://doi.org/10.1007/s12307-0140148-4

32. Malin D, Strekalova E, Petrovic V, Deal AM, Al Ahmad A, Adamo B, Miller CR, Ugolkov A, Livasy C, Fritchie K et al (2014) AlphaB-crystallin: a novel regulator of breast cancer metastasis to the brain. Clin Cancer Res 20:56-67. https://doi. org/10.1158/1078-0432.CCR-13-1255

33. Mihm MC Jr, Clemente CG, Cascinelli N (1996) Tumor infiltrating lymphocytes in lymph node melanoma metastases: a histopathologic prognostic indicator and an expression of local immune response. Lab Invest 74:43-47

34. Muller WJ, Sinn E, Pattengale PK, Wallace R, Leder P (1988) Single-step induction of mammary adenocarcinoma in transgenic mice bearing the activated c-neu oncogene. Cell $54: 105-115$

35. Mustafa DA, Dekker LJ, Stingl C, Kremer A, Stoop M, Sillevis Smitt PA, Kros JM, Luider TM (2012) A proteome comparison between physiological angiogenesis and angiogenesis in glioblastoma. Mol Cell Proteom 11(M111):008466. https://doi. org/10.1074/mcp.M111.008466

36. Mustafa DA, Sieuwerts AM, Smid M, de Weerd V, van der Weiden M, Meijer-van Gelder ME, Martens JW, Foekens JA, Kros JM (2015) A method to correlate mrna expression datasets obtained from fresh frozen and formalin-fixed, paraffin-embedded tissue samples: a matter of thresholds. PLoS One 10:e0144097. https:// doi.org/10.1371/journal.pone.0144097

37. Nayak L, Lee EQ, Wen PY (2012) Epidemiology of brain metastases. Curr Oncol Rep 14:48-54. https://doi.org/10.1007/s119 12-011-0203-y

38. Niikura N, Saji S, Tokuda Y, Iwata H (2014) Brain metastases in breast cancer. Jpn J Clin Oncol 44:1133-1140. https://doi. org/10.1093/jjco/hyu156 
39. Ohara M, Yamaguchi Y, Matsuura K, Murakami S, Arihiro K, Okada M (2009) Possible involvement of regulatory T cells in tumor onset and progression in primary breast cancer. Cancer Immunol Immunother 58:441-447. https://doi.org/10.1007/s002 62-008-0570-x

40. Olson EM, Abdel-Rasoul M, Maly J, Wu CS, Lin NU, Shapiro CL (2013) Incidence and risk of central nervous system metastases as site of first recurrence in patients with HER2-positive breast cancer treated with adjuvant trastuzumab. Ann Oncol 24:1526-1533. https://doi.org/10.1093/annonc/mdt036

41. Ostler N, Britzen-Laurent N, Liebl A, Naschberger E, Lochnit G, Ostler M, Forster F, Kunzelmann P, Ince S, Supper V et al (2014) Gamma interferon-induced guanylate binding protein 1 is a novel actin cytoskeleton remodeling factor. Mol Cell Biol 34:196-209. https://doi.org/10.1128/MCB.00664-13

42. Pedersen MH, Hood BL, Beck HC, Conrads TP, Ditzel HJ, LethLarsen R (2017) Downregulation of antigen presentation-associated pathway proteins is linked to poor outcome in triple-negative breast cancer patient tumors. Oncoimmunology 6:e1305531. http s://doi.org/10.1080/2162402X.2017.1305531

43. Pestalozzi BC, Holmes E, de Azambuja E, Metzger-Filho O, Hogge L, Scullion M, Lang I, Wardley A, Lichinitser M, Sanchez RI et al (2013) CNS relapses in patients with HER2-positive early breast cancer who have and have not received adjuvant trastuzumab: a retrospective substudy of the HERA trial (BIG 1-01). Lancet Oncol 14:244-248. https://doi.org/10.1016/S1470-2045 (13)70017-2

44. Ramakrishna N, Temin S, Chandarlapaty S, Crews JR, Davidson NE, Esteva FJ, Giordano SH, Gonzalez-Angulo AM, Kirshner JJ, Krop I et al (2014) Recommendations on disease management for patients with advanced human epidermal growth factor receptor 2-positive breast cancer and brain metastases: American Society of Clinical Oncology clinical practice guideline. J Clin Oncol 32:2100-2108. https://doi.org/10.1200/JCO.2013.54.0955

45. Riaz M, Setyono-Han B, Timmermans MA, Trapman AM, Boltde Vries J, Hollestelle A, Janssens RC, Look MP, Schutte M, Foekens JA et al (2014) Growth and metastatic behavior of molecularly well-characterized human breast cancer cell lines in mice. Breast Cancer Res Treat 148:19-31. https://doi.org/10.1007/s105 49-014-3142-0

46. Ridley AJ (2001) Rho GTPases and cell migration. J Cell Sci 114:2713-2722

47. Romagnoli M, Mineva ND, Polmear M, Conrad C, Srinivasan S, Loussouarn D, Barille-Nion S, Georgakoudi I, Dagg A, McDermott EW et al (2014) ADAM8 expression in invasive breast cancer promotes tumor dissemination and metastasis. EMBO Mol Med 6:278-294. https://doi.org/10.1002/emmm.201303373

48. Salgado R, Denkert C, Demaria S, Sirtaine N, Klauschen F, Pruneri G, Wienert S, Van den Eynden G, Baehner FL, PenaultLlorca $\mathrm{F}$ et al (2015) The evaluation of tumor-infiltrating lymphocytes (TILs) in breast cancer: recommendations by an International TILs Working Group 2014. Ann Oncol 26:259-271. http s://doi.org/10.1093/annonc/mdu450

49. Shao MM, Liu J, Vong JS, Niu Y, Germin B, Tang P, Chan AW, Lui PC, Law BK, Tan PH et al (2011) A subset of breast cancer predisposes to brain metastasis. Med Mol Morphol 44:15-20. http s://doi.org/10.1007/s00795-010-0495-2

50. Sieuwerts AM, Meijer-van Gelder ME, Timmermans M, Trapman AM, Garcia RR, Arnold M, Goedheer AJ, Portengen H, Klijn JG, Foekens JA (2005) How ADAM-9 and ADAM-11 differentially from estrogen receptor predict response to tamoxifen treatment in patients with recurrent breast cancer: a retrospective study. Clin Cancer Res 11:7311-7321. https://doi.org/10.1158/1078-0432 .CCR-05-0560

51. Simon R, Lam A, Li MC, Ngan M, Menenzes S, Zhao Y (2007) Analysis of gene expression data using BRB-ArrayTools. Cancer Inform 3:11-17

52. Smid M, Wang Y, Klijn JG, Sieuwerts AM, Zhang Y, Atkins D, Martens JW, Foekens JA (2006) Genes associated with breast cancer metastatic to bone. J Clin Oncol 24:2261-2267. https:// doi.org/10.1200/JCO.2005.03.8802

53. Smid M, Wang Y, Zhang Y, Sieuwerts AM, Yu J, Klijn JG, Foekens JA, Martens JW (2008) Subtypes of breast cancer show preferential site of relapse. Cancer Res 68:3108-3114. https://doi. org/10.1158/0008-5472.CAN-07-5644

54. Stark AM, Tongers K, Maass N, Mehdorn HM, Held-Feindt J (2005) Reduced metastasis-suppressor gene mRNA-expression in breast cancer brain metastases. J Cancer Res Clin Oncol 131:191198. https://doi.org/10.1007/s00432-004-0629-9

55. Straetemans T, van Brakel M, van Steenbergen S, Broertjes M, Drexhage J, Hegmans J, Lambrecht BN, Lamers C, van Der Bruggen P, Coulie PG et al (2012) TCR gene transfer: MAGEC2/HLA-A2 and MAGE-A3/HLA-DP4 epitopes as melanomaspecific immune targets. Clin Dev Immunol 2012:586314. http s://doi.org/10.1155/2012/586314

56. Tan W, Zhang W, Strasner A, Grivennikov S, Cheng JQ, Hoffman RM, Karin M (2011) Tumour-infiltrating regulatory T cells stimulate mammary cancer metastasis through RANKL-RANK signalling. Nature 470:548-553. https://doi.org/10.1038/nature09 707

57. Tomasello G, Bedard PL, de Azambuja E, Lossignol D, Devriendt D, Piccart-Gebhart MJ (2010) Brain metastases in HER2-positive breast cancer: the evolving role of lapatinib. Crit Rev Oncol Hematol 75:110-121. https://doi.org/10.1016/j.critrevonc.2009 .11 .003

58. Valiente M, Obenauf AC, Jin X, Chen Q, Zhang XH, Lee DJ, Chaft JE, Kris MG, Huse JT, Brogi E et al (2014) Serpins promote cancer cell survival and vascular co-option in brain metastasis. Cell 156:1002-1016. https://doi.org/10.1016/j.cell.2014.01.040

59. Van Swearingen AE, Siegel MB, Anders CK (2014) Breast cancer brain metastases: evidence for neuronal-like adaptation in a 'breast-to-brain' transition? Breast Cancer Res 16:304. https://doi. org/10.1186/bcr3651

60. Vizcaino JA, Csordas A, Toro N, Dianes JA, Griss J, Lavidas I, Mayer G, Perez-Riverol Y, Reisinger F, Ternent T et al (2016) 2016 update of the PRIDE database and its related tools. Nucleic Acids Res 44:D447-456. https://doi.org/10.1093/nar/gkv1145 